\title{
Design and Synthesis of Biaryl DNA-encoded Libraries $\uparrow$
}

\author{
Yun Ding, ${ }^{a}$ G. Joseph Franklin, ${ }^{a}$ Jennifer L. DeLorey, ${ }^{a}$ Paolo A. Centrella, ${ }^{b}$ Sibongile \\ Mataruse, ${ }^{a}$ Matthew A. Clark, ${ }^{b}$ Steven R. Skinner, ${ }^{a}$ Svetlana Belyanskaya ${ }^{a}$
}

\section{Supporting information}

\begin{abstract}
Methods
All solvents and reagents were used as obtained. ${ }^{1} \mathrm{H}$ NMR spectra were recorded on a Varian Mercury 400 Plus. Chemical shifts are expressed in parts per million (ppm, $\delta$ units). On-DNA reactions conducted during validation, library synthesis, or single compound synthesis were analyzed by LCMS. Samples (ca. 100 pmol) were injected onto a reverse-phase chromatography column (Targa C18, 5 $\mu, 2.1$ x $40 \mathrm{~mm}$ ) and eluted (15$70 \%$ solvent B over 7 minutes, $0.36 \mathrm{~mL} / \mathrm{min}$ flow rate; Solvent A: $0.75 \%$ hexafluoroisopropanol / $0.38 \%$ triethylammonium acetate $/ 10 \mu \mathrm{M}$ EDTA in deionized water; Solvent B: 0.75\% HFIP/0.38\% TEAA/10 $\mu$ M EDTA in 90/10 methanol/water) with monitoring at $260 \mathrm{~nm}$. Some samples were injected onto Effluent was analyzed on a ThermoFinnigan Advantage electrospray mass spectrometer in negative ion mode. When necessary, mass deconvolution was achieved using ProMass software (Novatia). Chromatographic purification was likewise achieved using reverse-phase liquid

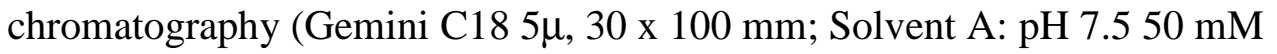
triethylammonium acetate; Solvent B: $1 \%$ water in acetonitrile).
\end{abstract}

\section{Synthesis of 5-formyl 3-iodobenzoic acid (1).}

At $50{ }^{\circ} \mathrm{C}$, the solution of 5-iodoisophthalate $(5.0 \mathrm{~g}, 15.625 \mathrm{mmol})$ and $\mathrm{NaBH}_{4}$ (591 mg, $15.625 \mathrm{mmol})$ in anhydrous THF (50 ml) was added dropwise $\mathrm{MeOH}(5 \mathrm{ml})$. The reaction mixture was continued stirred at $45^{\circ} \mathrm{C}-50{ }^{\circ} \mathrm{C}$ for about $1 \mathrm{hr}$. The reaction solution was diluted with EtOAc (125 ml), washed with water $(3 \mathrm{x})$ and brine $(1 \mathrm{x})$. The organic phase was separated, dried over $\mathrm{MgSO}_{4}$ and concentrated to give yellowish oil, which was further purified with silica gel (eluant 20 30\% EtOAc/hexanes) to give the desired mono-reduced product methyl 3-(hydroxylmethyl)-5-iodobenzoate (3.3 g, $72 \%$ yield). ${ }^{1} \mathrm{HNMR}\left(\mathrm{CDCl}_{3}, 400 \mathrm{MHz}\right) \delta 8.26(\mathrm{~s}, 1 \mathrm{H}), 7.96(\mathrm{~s}, 1 \mathrm{H}), 7.91(\mathrm{~s}, 1 \mathrm{H}), 4.70$ (s, 2 $\mathrm{H}), 3.91$ (s, $3 \mathrm{H})$.

A solution of methyl 3-(hydroxylmethyl)-5-iodobenzoate (3.3 g) in EtOAc (33 $\mathrm{ml})$ was added $\mathrm{MnO}_{2}(\sim 85 \%$ purity, $22 \mathrm{~g})$. The reaction was heated under refluxing for about $4 \mathrm{hrs}$. Filter out the solid. The filtrate was evaporated to give the desired product which was pure enough to carry onto next step without purification. ${ }^{1} \mathrm{HNMR}\left(\mathrm{CDCl}_{3}, 400\right.$ MHz) $\delta 9.98(\mathrm{~s}, 1 \mathrm{H}), 8.61(\mathrm{~s}, 1 \mathrm{H}), 8.47(\mathrm{~s}, 1 \mathrm{H}), 8.39$ (s, $1 \mathrm{H}), 3.97$ (s, 3H).

A solution of methyl 3-formyl-5-iodobenzoate (110 mg, $0.38 \mathrm{mmol})$ in $\mathrm{MeOH}$ (1 $\mathrm{ml})$ was added $1 \mathrm{M} \mathrm{NaOH}(2 \mathrm{ml})$. The reaction was stirred at room temperature for about $2 \mathrm{hrs}$. Acidify the reaction solution with acetic acid to $\sim \mathrm{pH} 5$. The solvent was evaporated 
and the crude was further purified by preparative HPLC to afford the final compound (1) (100 mg, 96\%). ${ }^{1} \mathrm{HNMR}\left(\mathrm{CDCl}_{3}, 400 \mathrm{MHz}\right) \delta 10.00(\mathrm{~s}, 1 \mathrm{H}), 8.68(\mathrm{~s}, 1 \mathrm{H}), 8.55(\mathrm{~s}, 1 \mathrm{H})$, $8.46(\mathrm{~s}, 1 \mathrm{H})$.

\section{"Headpiece" (HP) Sequence: 5'-/5Phos/GAGTCA/iSp9/iUniAmM/iSp9/TGACTCCC- $3^{\prime}$}

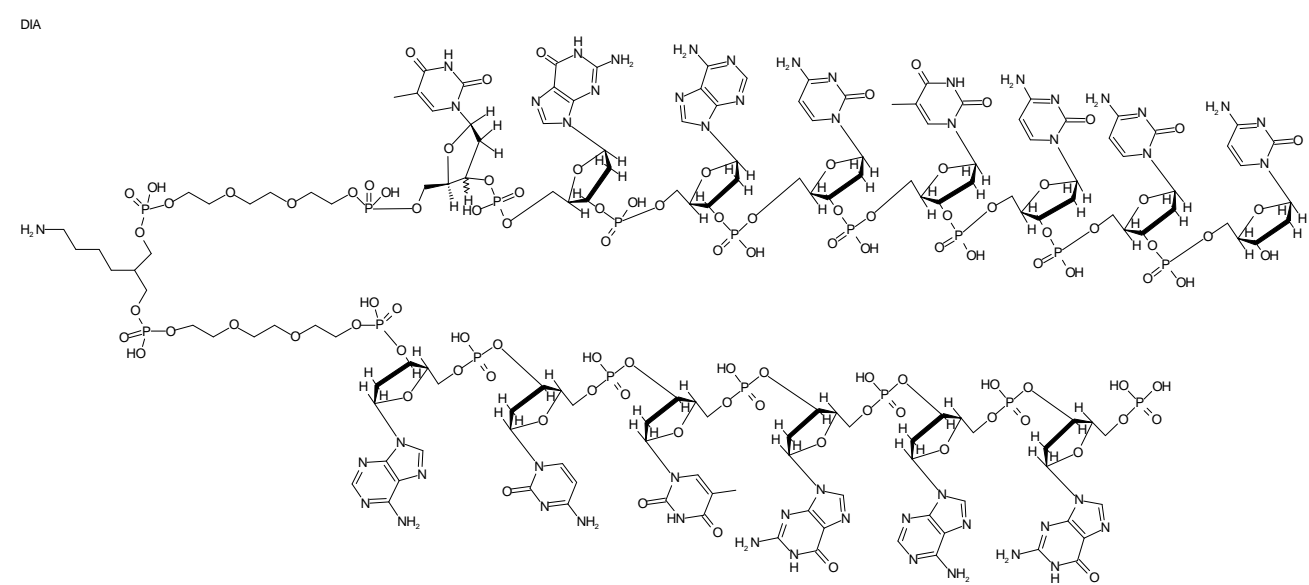

Figure 1. Sequence and structure of the "headpiece." MW $=4937 \mathrm{D}$

General procedure for the acylation of acid with HP: A solution of HP in $\mathrm{pH} 9.4$ borate buffer $(250 \mathrm{mM})(1 \mathrm{mM})$ was added at cold 40 equivalents of acid, followed by adding 40 equivalents of DMT-MM. After being kept at cold for 10 minutes, the reaction was allowed to proceed at room temperature overnight. The reaction was precipitated by adding $10 \% 5 \mathrm{~N} \mathrm{NaCl}$ water solution and 2.5 times volume of absolute EtOH. The pellet was redissolved in water to make $1 \mathrm{mM}$ concentration, followed by adding $10 \%$ volume of piperidine. The reaction was allowed to proceed at room temperature for a couple hours. The headpiece was precipitated by treating with $\mathrm{EtOH}$ as previous.

\section{General procedure for the Suzuki coupling with HP-3.}

A $1 \mathrm{mM}$ solution of HP-3 in water ( $20 \mathrm{nmol}, 20 \mu \mathrm{L}$ ) was added 40 equivalents of boronate $\left(1 \mu \mathrm{L}, 800 \mathrm{mM}\right.$ in DMA) and 80 equivalents of $\mathrm{Na}_{2} \mathrm{CO}_{3}(1.3 \mu \mathrm{L}, 1.2 \mathrm{M}$ in water), followed by 1 equivalent of degassed $\mathrm{Pd}\left(\mathrm{PPh}_{3}\right)_{4}\left(6.7 \mu \mathrm{L}, 3 \mathrm{mM}\right.$ in $\left.\mathrm{CH}_{3} \mathrm{CN}\right)$. The reaction was allowed to proceed at $80{ }^{\circ} \mathrm{C}$ for 4 hours.

General procedure for the reductive amination with aldehyde linked on HP. A $1 \mathrm{mM}$ solution of aldehyde $\mathbf{H P}$ in $\mathrm{pH} 5.5$ sodium phosphate buffer $(250 \mathrm{mM})$ was added 100 equivalents of amine $\left(200 \mathrm{mM}\right.$ in $\left.\mathrm{CH}_{3} \mathrm{CN}\right)$ and 100 equivalents of $\mathrm{NaCNBH}_{3}$ ( $200 \mathrm{mM}$ in $\mathrm{CH}_{3} \mathrm{CN}$ ). The reaction was allowed to proceed at room temperature overnight.

General procedure for the reductive alkylation with secondary amine linked on HP. A $1 \mathrm{mM}$ solution of secondary amine $\mathbf{H P}$ in $\mathrm{pH} 5.5$ sodium phosphate buffer $(250 \mathrm{mM})$ (10 nmol, $10 \mu \mathrm{L}$ ) was added 40 equivalents of aldehyde $\left(2 \mu \mathrm{L}, 200 \mathrm{mM}\right.$ in $\mathrm{CH}_{3} \mathrm{CN}$ ) and 
40 equivalents of $\mathrm{NaCNBH}_{3}\left(2 \mu \mathrm{L}, 200 \mathrm{mM}\right.$ in $\left.\mathrm{CH}_{3} \mathrm{CN}\right)$. The reaction was allowed to proceed at $60{ }^{\circ} \mathrm{C}$ overnight or at $80^{\circ} \mathrm{C}$ for 4 hours.

\section{Synthon Validation}

All synthons were validated in 96-well plates using library-like conditions. Analysis was performed using LCMS as described above.

The validation of boronic acids/esters was done on simpler headpiece (HP-1).

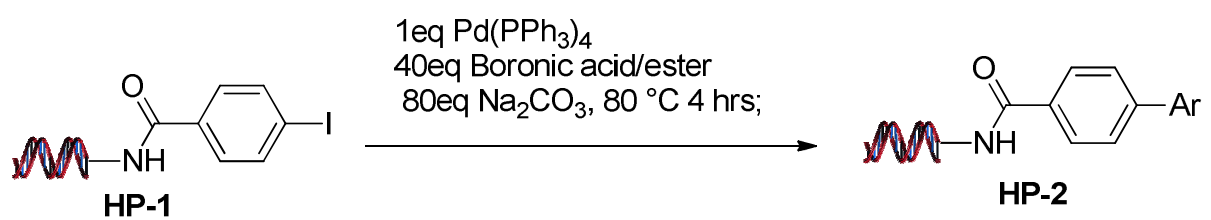

The validation process ran as follows: A $1 \mathrm{mM}$ solution of HP-1 in water was arrayed into a 96 well plate $(20 \mathrm{nmol} /$ well, $20 \mu \mathrm{L})$. To each well was then added 80 equivalents of $\mathrm{Na}_{2} \mathrm{CO}_{3}\left(2.6 \mu \mathrm{L}\right.$ of a $600 \mathrm{mM}$ solution in $\left.\mathrm{H}_{2} \mathrm{O}\right), 40$ equivalents of boronic acid or boronic ester (1.3 $\mu \mathrm{L}$ of a $600 \mathrm{mM}$ solution in DMA), followed by addition of 1 equivalent of $\mathrm{Pd}$ $\left(\mathrm{PPh}_{3}\right)_{4}\left(6.7 \mu \mathrm{L}\right.$ of $3 \mathrm{mM}$ in $\mathrm{CH}_{3} \mathrm{CN}$, sonicated for $\left.5 \mathrm{mins}\right)$. The reactions were allowed to proceed at $80{ }^{\circ} \mathrm{C}$ for $4 \mathrm{hrs}$. An aliquot of the reaction solution was removed for LCMS analysis.

A total of 153 boronic acids/esters were validated. Of those, 107 passed at a yield of greater than $70 \%$.

Yields were calculated by examination of the UV and TIC traces of the LCMS chromatograms. De-iodide side product was identified and excluded from the product percentage. In addition, products in which the DNA was damaged by gain or loss of mass, such as depurination, phosphate hydrolysis, or covalent modification, were likewise excluded from the product percentage (such products were seen very rarely). It should be noted that, because mass is the only means of analysis, the validation procedure provided no information about stereo- or regioselectivity when applicable. While isomerism of this type complicated the post-selection chemistry campaign, it did not compromise the ligand-generating ability of the library.

Example of boronic acids/esters that will be applied in the library synthesis. 


\begin{tabular}{|l|l|}
\hline & validation yield \\
\hline & \\
\hline
\end{tabular}




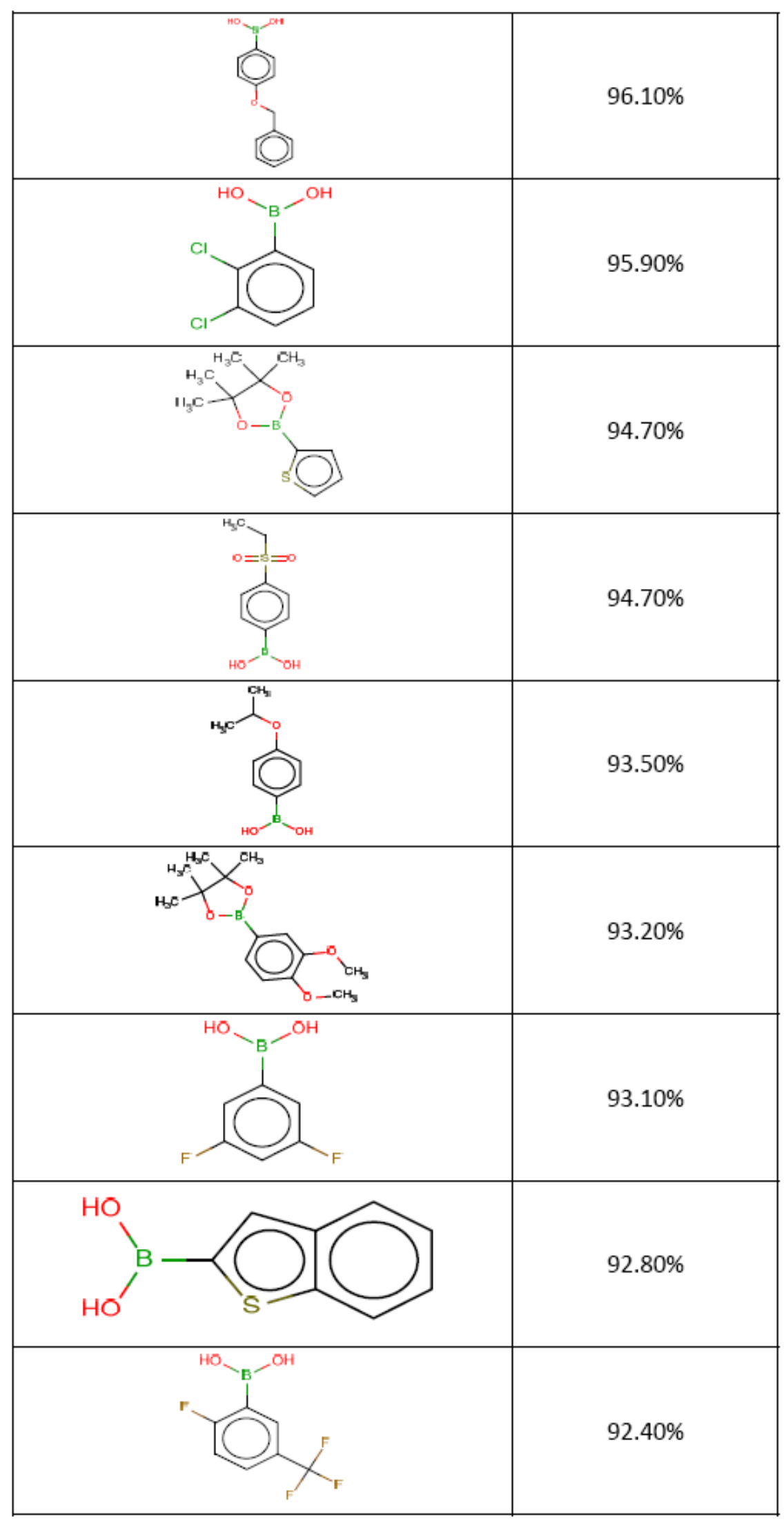




\begin{tabular}{|l|l|}
\hline & $80.60 \%$ \\
\hline & $88.90 \%$ \\
\hline & 88.10 \\
\hline
\end{tabular}




\begin{tabular}{|l|l|}
\hline & $83.60 \%$ \\
\hline & $83.40 \%$ \\
\hline & 81.20 \\
\hline
\end{tabular}


The validation of reductive amination was done on HP-3.
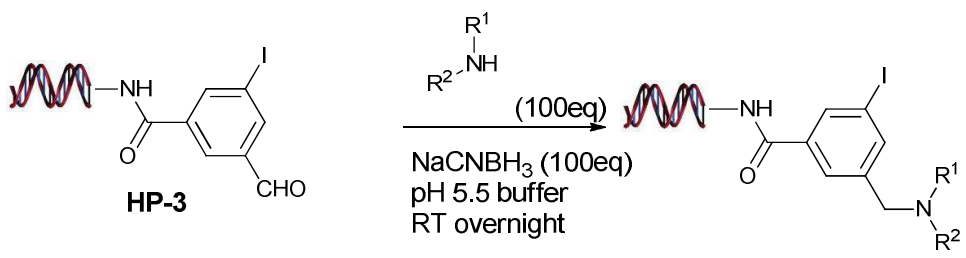

The validation process ran as follows: A $1 \mathrm{mM}$ solution of HP-3 in $250 \mathrm{mM}$ phosphate buffer $\mathrm{pH} 5.5$ was arrayed into a 96 well plate $(10 \mathrm{nmol} / \mathrm{well}, 10 \mu \mathrm{L})$. To each well was then added amine (100 equiv of a $200 \mathrm{mM}$ DMA stock) and sodium cyanoborohydride (100 equiv of a $200 \mathrm{mM} \mathrm{CH}_{3} \mathrm{CN}$ stock). The reaction was allowed to proceed for $16 \mathrm{~h}$ at room temperature, at which point the DNA was precipitated by addition of $5 \mathrm{M} \mathrm{NaCl}$ ( $10 \%$ by volume) and 2.5 volumes of cold ethanol. The DNA pellets were redissolved in $10 \mu \mathrm{L}$ water. An aliquot was removed from each well for LCMS analysis.

Totally 831 amines were validated. Of those, 218 passed at a yield of greater than $70 \%$.

Examples of amines applied in the library production: 


\begin{tabular}{|l|l|}
\hline & validation yield (\%) \\
\hline
\end{tabular}




\begin{tabular}{|l|l|}
\hline & \\
\hline
\end{tabular}




\begin{tabular}{|l|l|}
\hline & 83.4 \\
\hline & 83.5 \\
\hline
\end{tabular}




\begin{tabular}{|l|l|}
\hline & \\
\hline
\end{tabular}




\begin{tabular}{|l|l|}
\hline & 95.1 \\
\hline
\end{tabular}

\section{Test Library}

Further validation of our library synthetic plan was achieved through the synthesis of a small test library. A library similar to DEL-A was synthesized with a total diversity of 8 compounds. 


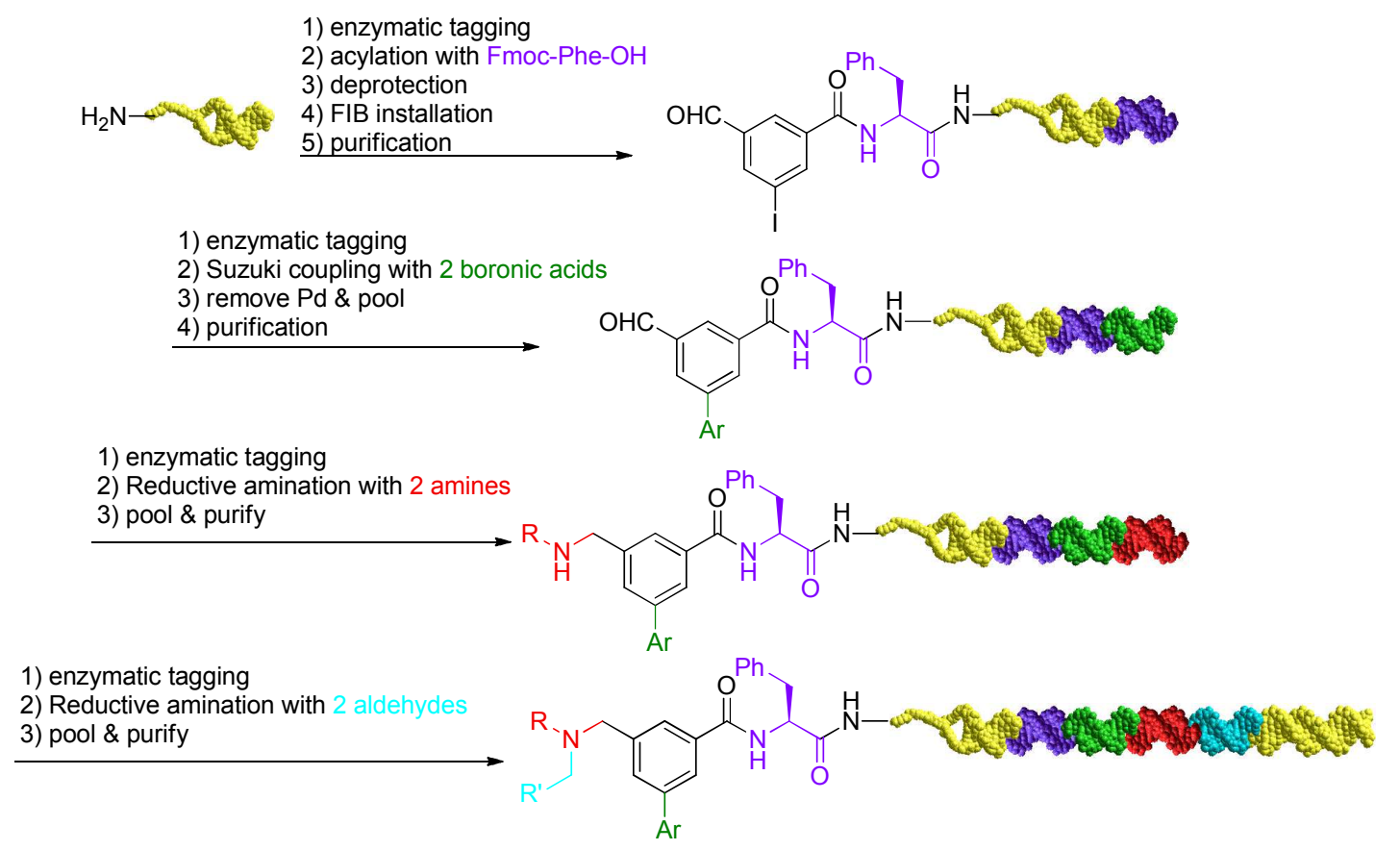

Boronic acids for Cycle 2:<smiles>CN(C)CCCNC(=O)c1cccc(B(O)OCc2ccccc2)c1</smiles>

Amines for Cycle 3:<smiles>NCCOc1ccccc1Cl</smiles>

Aldehydes for Cycle 4:<smiles>O=Cc1ccco1</smiles>

After completion of the test library synthesis, the DNA portion of the library was digested using a combination of DNase and S1 Nuclease (Invitrogen) as per the manufacturer's instructions. This process left the library products attached to the linker and a single nucleotide: 


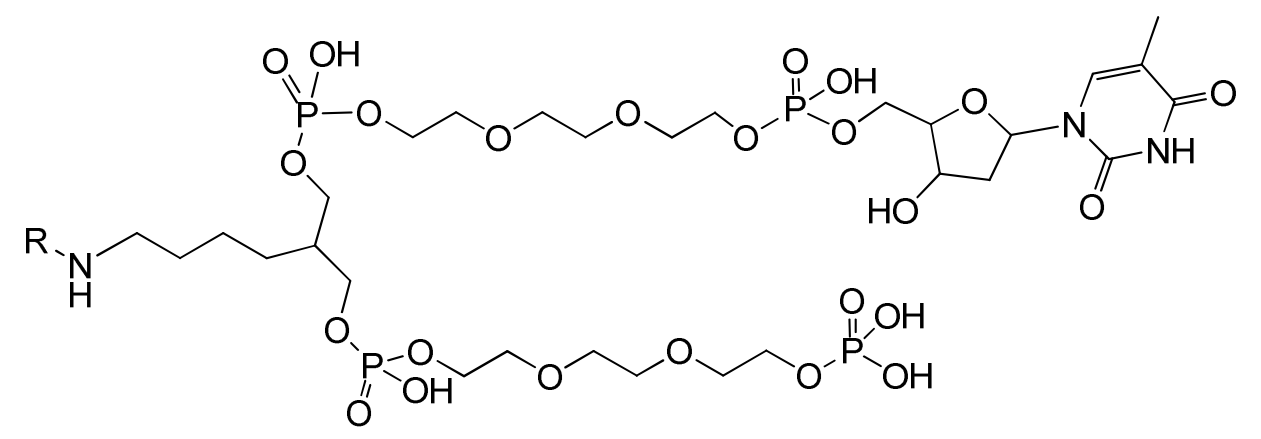

The digested library sample was analyzed by LCMS. All 8 of the expected masses (and their $\mathrm{Na}$ adducts) were observed, as well as several expected byproducts:

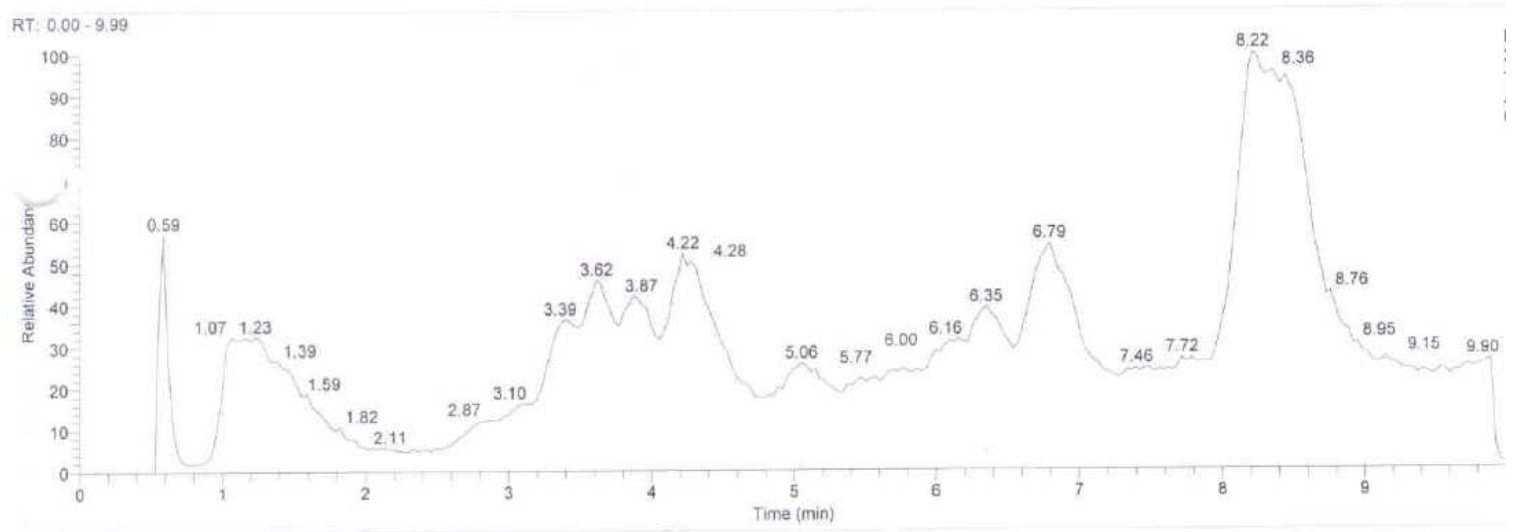

JLS.D17M-C4digA2 $\approx 250-260$ RT: $798-827$ AV: 11 NL: 2.85E6

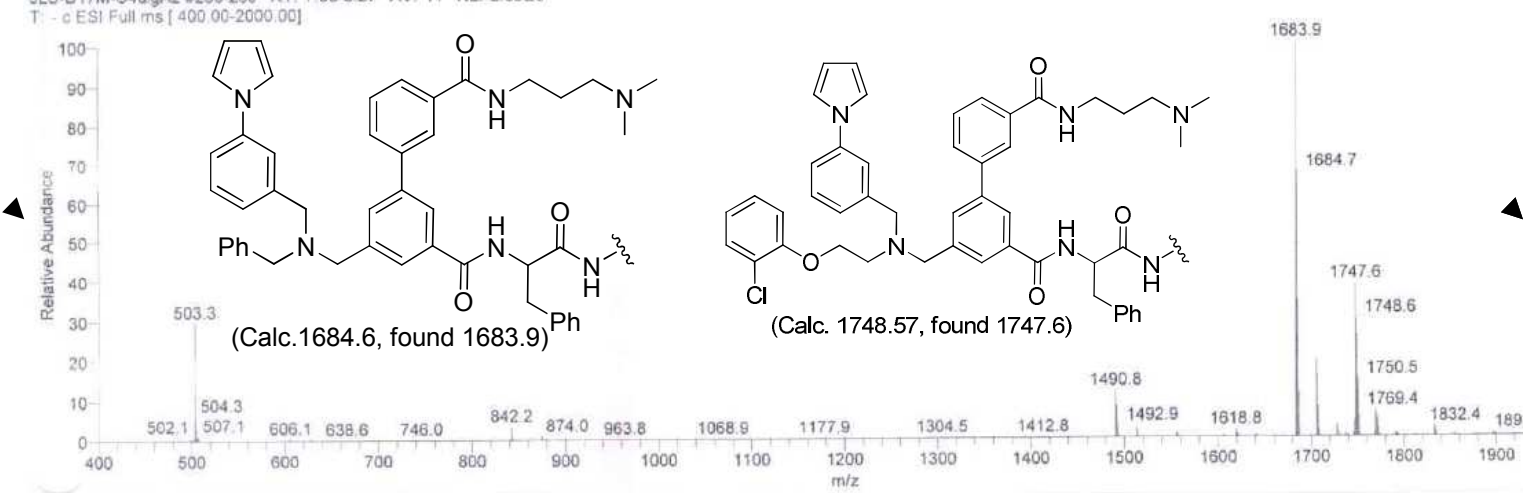

JLS-D17M-C4digA2 \#262-282 RT: $8.33-8.92$ AV: 21 NL: $1.45 E 6$

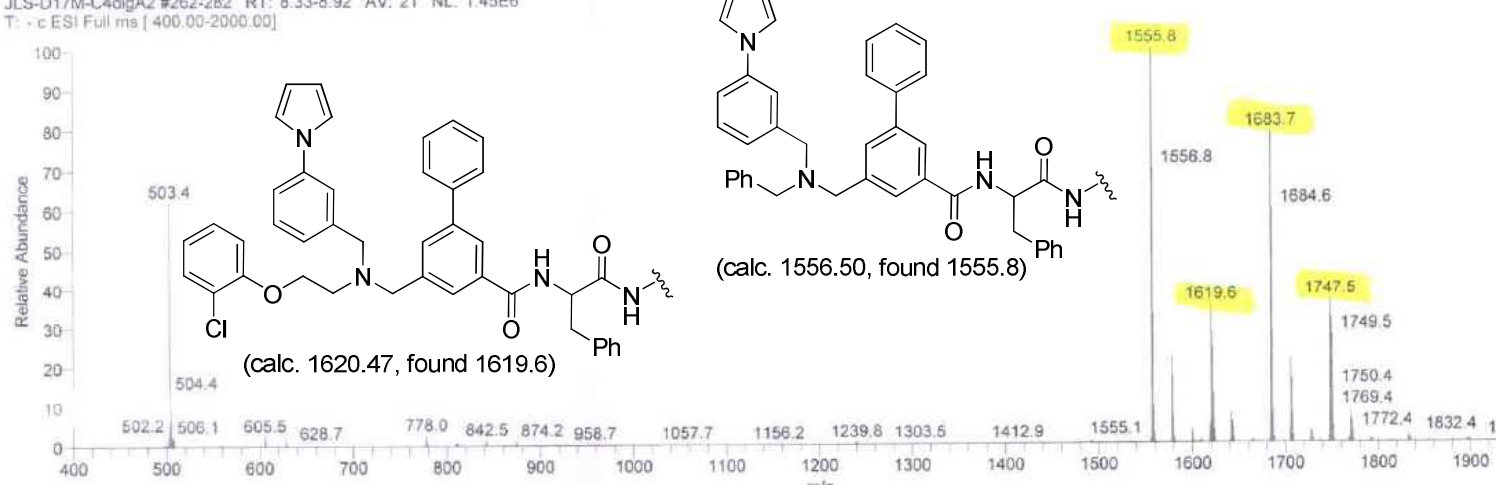




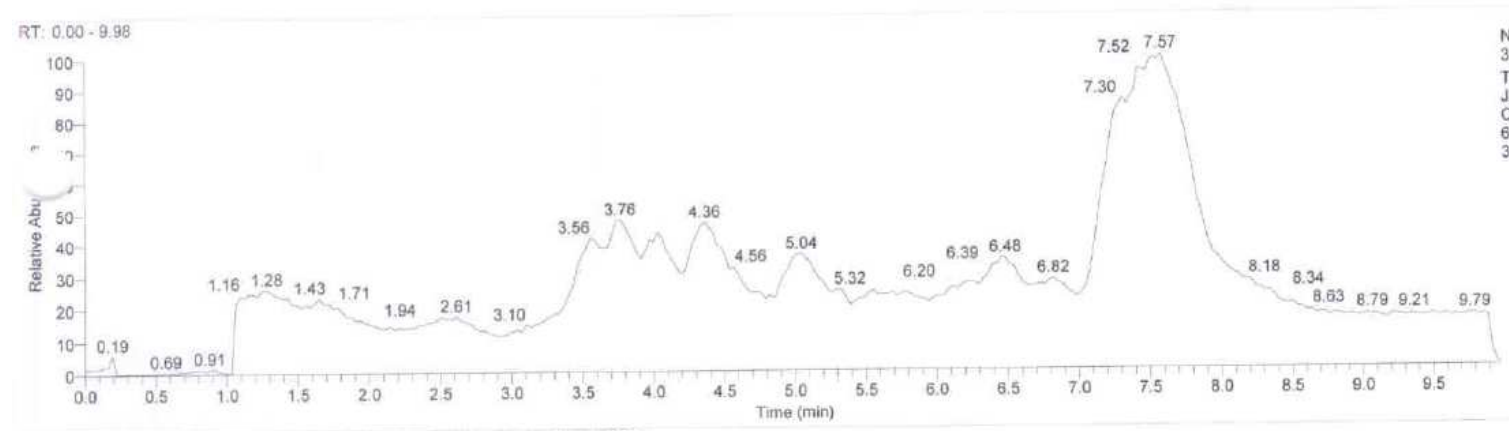

JLS-D17M-CAdig82 060310141738 \#214-223 RT: $6.73-7.01$ AV: 10 NL: 1.17EQ

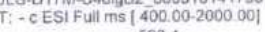

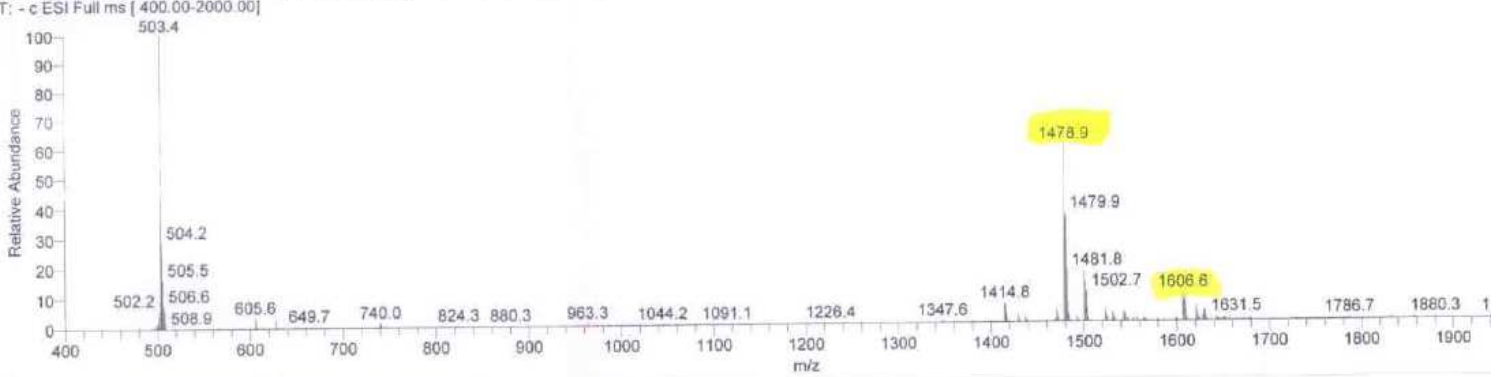

JLS-D17M-C4digB2 060310141738 \#223-232 RT: 7.01-7.27 AV: 10 NL: $4.59 E$ E T: - c ESI Full ms [ $400.00-2000.00]$

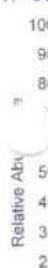

-

80
1

50

40
30
20
10

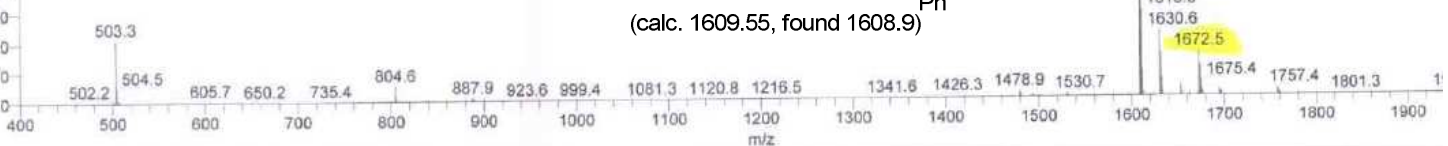

JLS-D17M-C4dig82 060310141738 \$229-242 RT: 7.19-7.55 AV: 14 NL: 4.31E6

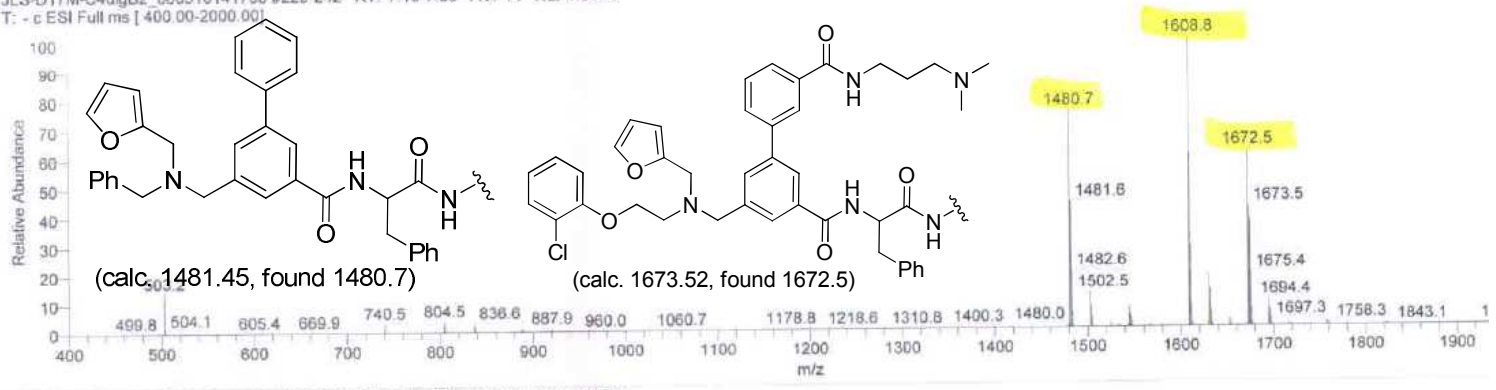

ILS.D17M.C4digB2 OE0310141738 \#238-251 RT $744-7.79$ AV: 14 NL: 497 E6

T. - c ESI Full ms [ 400.00-2000,00]

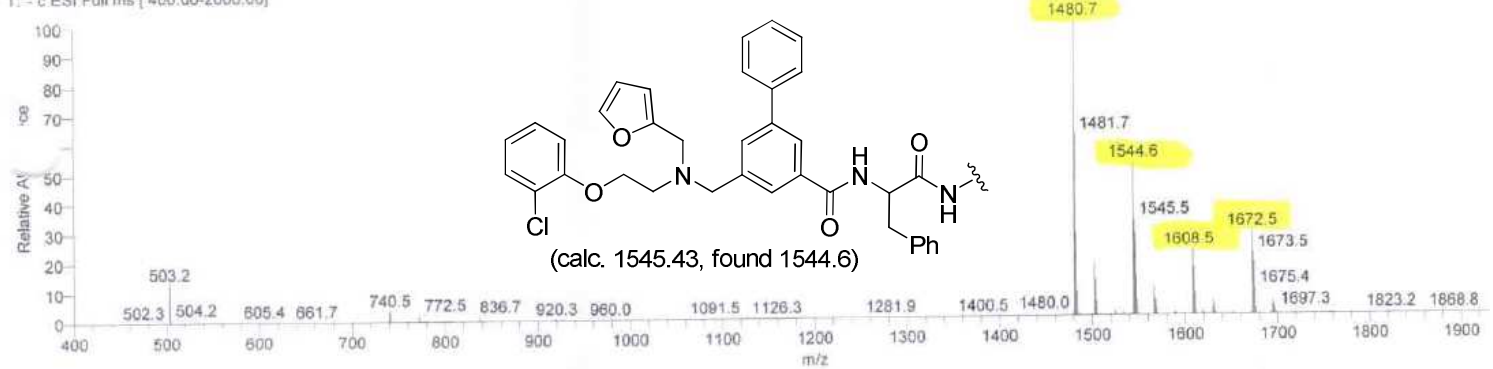




\section{The procedures for the synthesis of the library are described below.}

\section{Library Synthesis Starting Materials:}

Chemical building blocks (Fmoc-Protected amino acids, boronic acids/ esters and aldehydes) were obtained from commercial sources. Building blocks were dissolved in appropriate solvents for use (See Methods). DNA headpiece (5' -15 phos/GAGTCA/iSp9/iUniAmM/iSp9/TGACTCCC-3') and the various DNA tags were obtained from IDT, Inc., Coraville, IA and Biosearch Technologies, Novato, CA. T4 DNA Ligase was obtained from Fermentas $(30 \mathrm{U} / \mu \mathrm{l})$. The $10 \mathrm{X}$ ligation buffer stock used in ligation reactions was composed of the following: $500 \mathrm{mM}$ Tris $\mathrm{pH} 7.5,500 \mathrm{mM} \mathrm{NaCl}$, $100 \mathrm{mM} \mathrm{MgCl} 2,100 \mathrm{mM}$ DTT and $25 \mathrm{mM}$ ATP.

Installation of chemical spacer. A $40 \mathrm{~mL}$ solution of headpiece DNA, (1 mM in 250 $\mathrm{mM}$ pH 9.4 borate buffer) was reacted with 40 equivalents of Fmoc-15-amino-4,7,10,13tetraoxapentadecanoic acid ("AOP”) ( $8.0 \mathrm{ml}$ of a $200 \mathrm{mM}$ DMF solution) followed by the addition of 40 equivalents of 4-(4,6-dimethoxy-1,3,5-triazin-2-yl)-4-methylmorpholinium chloride (DMT-MM) ( $8.0 \mathrm{~mL}$ of a $200 \mathrm{mM} \mathrm{H}_{2} \mathrm{O}$ solution). The reaction was allowed to proceed at room temperature overnight. Following completion, as monitored by LCMS, the reaction was precipitated by the addition of $5.6 \mathrm{~mL}$ of $5 \mathrm{M} \mathrm{NaCl}(10 \% \mathrm{v} / \mathrm{v})$ and 154 $\mathrm{mL}$ ( 2.5 volumes) of cold ethanol. The sample was placed in $-80{ }^{\circ} \mathrm{C}$ freezer for 60 minutes followed by centrifugation for 60 minutes. The resulting DNA pellet was dried on a lyophilizer. The dried pellet was then dissolved in $40 \mathrm{~mL}$ of $10 \% \mathrm{v} / \mathrm{v}$ piperidine in water for deprotection of amine. The deprotected product was precipitated with ethanol as previously described. The resulting lyophilized pellet was dissolved in $40 \mathrm{~mL}$ of water $(1 \mathrm{mM})$.

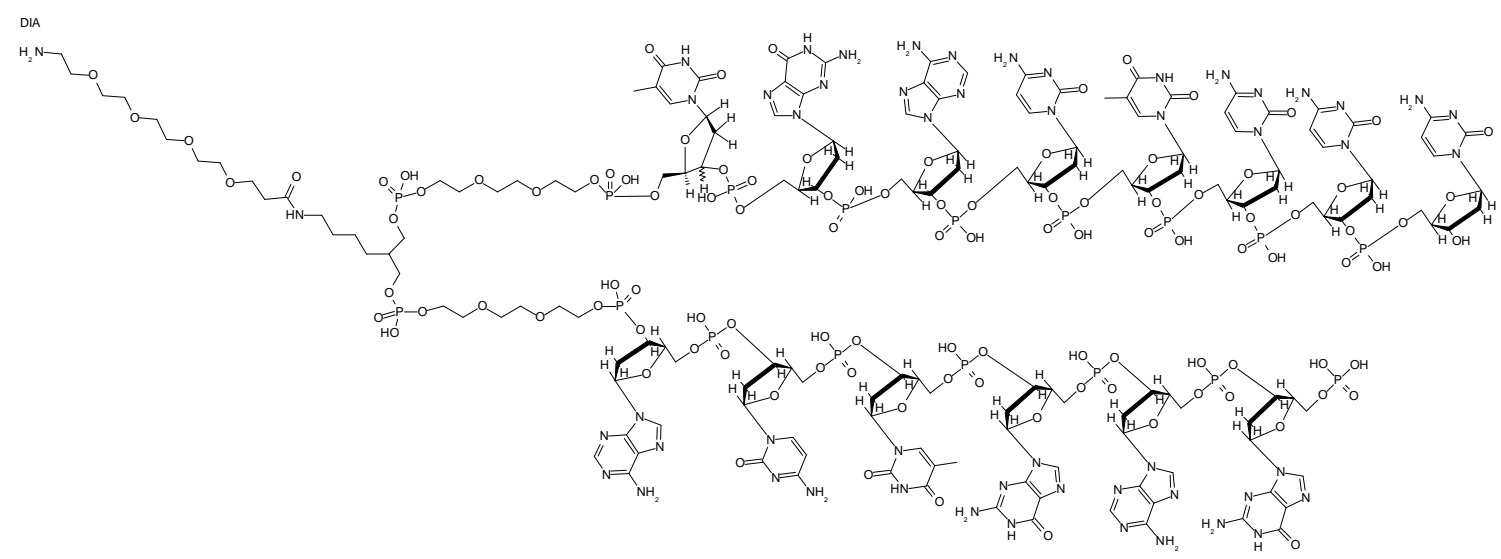

Figure 2. Structure of AOP-Headpiece. $\mathrm{MW}=5184 \mathrm{D}$

Primer Ligation. The $40 \mu \mathrm{mol}\left(1 \mathrm{mM}\right.$ in $\left.\mathrm{H}_{2} \mathrm{O}\right)$ of AOP-Headpiece was enzymatically ligated with a PCR primer duplex (60 mL of a $1 \mathrm{mM}$ solution in $\mathrm{H}_{2} \mathrm{O}, 1.5$ equivalents). An additional $22 \mathrm{~mL}$ of $\mathrm{H}_{2} \mathrm{O}, 16 \mathrm{~mL}$ of $10 \mathrm{X}$ ligation buffer and $1.6 \mathrm{~mL}$ of T4 DNA ligase (Fermentas, $30 \mathrm{U} / \mu \mathrm{L}$ ) was added to the headpiece and primer. The reaction mixture was incubated at $16{ }^{\circ} \mathrm{C}$ for $16 \mathrm{hrs}$. The sample was analyzed by LCMS and gel. 
The completed reaction was precipitated with $\mathrm{NaCl}$ and ethanol and taken onto the first diversity cycle of library synthesis.

Sequence of primer tags $(\mathrm{MW}=6863.26)$
$\begin{array}{lll}5^{\prime} & \text { AAATCGATGTG } & 3^{\prime} \\ 3^{\prime} & \text { GGTTTAGCTAC } & 5^{\prime}\end{array}$

Sequence of the extended headpiece $(\mathrm{MW}=12011 \mathrm{D})$ :
$\begin{cases}\text { TGACTCCCAAATCGATGTG } & 3^{\prime} \\ \text { ACTGAGGGTTTAGCTAC } & 5^{\prime}\end{cases}$

Tags. The DNA tags contained a 7bp coding region, flanked by two 2-base 3' overhangs: All 5'-ends were phosphorylated.

\begin{tabular}{|c|c|c|}
\hline & Cycle 1 & Cycle 2 \\
\hline $5^{\prime}$ & XXXXXXXAG & XXXXXXXGT \\
\hline $3^{\prime}$ & ACXXXXXXX & TCXXXXXXX \\
\hline & Cycle 3 & Cycle 4 \\
\hline $5^{\prime}$ & XXXXXXXGA & XXXXXXXTT \\
\hline $3^{\prime}$ & CAXXXXXXX & CTXXXXXXX \\
\hline
\end{tabular}

Cycle 1. A $1 \mathrm{mM}$ solution of the primer-elongated AOP-Headpiece $(40 \mu \mathrm{mol}, 40 \mathrm{~mL}$ $\mathrm{H}_{2} \mathrm{O}$ ) was split into 768 wells (52 nmol of headpiece/ well). 384 cycle 1 specific tags (104 $\mu \mathrm{L}$ of a $1 \mathrm{mM}$ in water) were added to 768 wells (each tag had a duplicate well). Next was added $20 \mu \mathrm{L}$ of $10 \mathrm{X}$ ligation buffer, $2 \mu \mathrm{L}$ of T4 DNA ligase and $28 \mu \mathrm{L}$ of $\mathrm{H}_{2} \mathrm{O}$. The reaction mixture was incubated at $16{ }^{\circ} \mathrm{C}$ for $16 \mathrm{~h}$. After ligation confirmation by gel analysis the wells were precipitated with $21 \mu \mathrm{L}$ of $\mathrm{NaCl}$ and $525 \mathrm{uL}$ of cold ethanol and centrifuged. The resulting pellets were dried and dissolved in $52 \mu \mathrm{L}$ of $\mathrm{pH} 9.4$ borate buffer. The cycle 1 library solutions were cooled to $4{ }^{\circ} \mathrm{C}$ and to each well 40 equivalents of 1 of 192 Fmoc-amino acids (10.4 $\mu \mathrm{L}$ of a $200 \mathrm{mM}$ solution in DMF), followed immediately by the addition of 40 equivalents of DMT-MM $(10.4 \mu \mathrm{L}$ of a $200 \mathrm{mM}$ solution in $\mathrm{H}_{2} \mathrm{O}$ ). After $2 \mathrm{hrs}$, a second addition of 40 equivalents of the same Fmocamino acid and DMT-MM solution was added to the wells. The acylations were allowed to proceed for $16 \mathrm{hrs}$ at $4{ }^{\circ} \mathrm{C}$. After completion the reactions were QC'd by LCMS, pooled and precipitated with ethanol. The lyophilized product was deprotected in $10 \%$ v/v piperidine in $\mathrm{H}_{2} \mathrm{O}$ for $2 \mathrm{hrs}$. The deprotected product was ethanol precipitated and the resulting pellet was dried. Since 384 tags were used for 192 synthons each synthon was encoded by 2 different tags. The resulting cycle 1 material was carried onto core installation step prior to purification. 
Core Installation. To the pooled library, 40 equivalents of the 3-formyl-5-iodobenzoic acid scaffold ( $8 \mathrm{~mL}$ of a $200 \mathrm{mM}$ solution in DMF) were added, followed immediately by addition of 40 equivalents of DMT-MM ( $8 \mathrm{~mL}$ of a $200 \mathrm{mM}$ solution in $\mathrm{H}_{2} \mathrm{O}$ ). After 16 hrs a second addition of 40 equivalents of the same 3-Formyl-5-iodobenzoic acid scaffold and DMT-MM solution was added to the wells. The acylations were allowed to proceed for $16 \mathrm{hrs}$ at room temperature. After completion, the pooled reaction was precipitated with ethanol and the resulting pellet was dried and dissolved in $40 \mathrm{~mL}$ of water for reverse-phase purification. After purification and lyophilization the pellet was dissolved in $20 \mathrm{~mL}$ of water and the yield was determined by $\operatorname{OD}_{260}(\varepsilon=563,896)$. The yield of the purified and deprotected cycle 1 library product plus 3-Formyl-5-iodobenzoic acid core was determined to be $32 \mu \mathrm{mol}$. To this material was added an additional $12 \mathrm{~mL}$ of water to get the concentration to $1 \mathrm{mM}$.

Cycle 2. The cycle 1 core (3-formyl-5-iodobenzoic acid) capped product (32 umol in $32 \mathrm{~mL}$ of $\mathrm{H}_{2} \mathrm{O}, 1 \mathrm{mM}$ ) was split into 384 wells ( $80 \mu \mathrm{L}$ of pooled library/ well). To each well $160 \mu \mathrm{L}$ of cycle 2 specific DNA tags was added (tags were $1 \mathrm{mM}$ in $\mathrm{H}_{2} \mathrm{O}$ ). To each well was added $32 \mathrm{uL}$ of $10 \mathrm{X}$ ligation buffer, $3.2 \mu \mathrm{L}$ of T4 DNA ligase and $44.25 \mu \mathrm{L}$ of $\mathrm{H}_{2} \mathrm{O}$ to each well. The ligations were incubated at $16{ }^{\circ} \mathrm{C}$ for $16 \mathrm{hrs}$. After ligation was confirmed by gel analysis the wells were precipitated with $33 \mu \mathrm{L}$ of $\mathrm{NaCl}$ and $830 \mu \mathrm{L}$ of cold ethanol and centrifuged. The resulting pellets were dried and dissolved in $80 \mu \mathrm{L}$ of $\mathrm{H}_{2} \mathrm{O}$. To each well of the cycle 2 library solutions was added 80 equivalents of $\mathrm{Na}_{2} \mathrm{CO}_{3}$ ( $10.6 \mu \mathrm{L}$ of a $600 \mathrm{mM}$ solution in $\mathrm{H}_{2} \mathrm{O}$ ), followed immediately by the addition of 40 equivalents of 1 of 96 boronic acids or boronic esters $(5.3 \mu \mathrm{L}$ of a $600 \mathrm{mM}$ solution in DMA), followed by addition of 1 equivalent of $\mathrm{Pd}\left(\mathrm{PPh}_{3}\right)_{4}\left(26.7 \mu \mathrm{L}\right.$ of $3 \mathrm{mM}$ in $\mathrm{CH}_{3} \mathrm{CN}$, degassed for 5 mins). The reactions were allowed to proceed at $80{ }^{\circ} \mathrm{C}$ for $16 \mathrm{hrs}$. After the reactions were complete the wells were pooled and the pooled sample was centrifuged to pelletize the precipitated palladium species. The supernatant containing the library was separated from the palladium species pellet and precipitated with cold ethanol, centrifuged and purified by reverse-phase HPLC. The purified and lyophilized cycle 2 library product was dissolved in $10 \mathrm{~mL}$ of $\mathrm{H}_{2} \mathrm{O}$ and yield was determined by $\mathrm{OD}_{260}(\varepsilon=765,490)$. The yield of the purified cycle 2 library products was determined to be $15 \mu$ moles. Since 384 tags were used for 96 synthons each synthon was encoded by 4 different tags. The purified cycle 2 library product was adjusted to $1 \mathrm{mM}$ by addition of 5 $\mathrm{mL}$ of $\mathrm{H}_{2} \mathrm{O}\left(15 \mu\right.$ moles of library in $15 \mathrm{~mL}$ of $\left.\mathrm{H}_{2} \mathrm{O}\right)$.

Cycle 3. The cycle 2 product $(4 \mu \mathrm{mol})$ was split in 192 wells $(20.8 \mu \mathrm{L}$ per well). To each well were added 2 equivalents of cycle 3 specific DNA tags $(41.6 \mu \mathrm{L}$ of a $1 \mathrm{mM}$ solution in $\mathrm{H}_{2} \mathrm{O}$ ). We then added $4 \mu \mathrm{L}$ of $10 \mathrm{X}$ ligation buffer, $0.4 \mu \mathrm{L}$ of T4 DNA ligase and $5.6 \mathrm{uL}$ of $\mathrm{H}_{2} \mathrm{O}$ to each well. The ligations were incubated at $16{ }^{\circ} \mathrm{C}$ for $16 \mathrm{hrs}$. After ligation was confirmed by gel analysis the wells were precipitated with $5 \mu \mathrm{L}$ of $\mathrm{NaCl}$ and $125 \mu \mathrm{L}$ of cold ethanol and centrifuged. The resulting pellets were dried and then dissolved at $1 \mathrm{mM}$ in $21 \mu \mathrm{L}$ of a $150 \mathrm{mM} \mathrm{pH} 5.5$ phosphate buffer. To each well was added 100 equivalents of amine $\left(10.4 \mu \mathrm{L}\right.$ of a $200 \mathrm{mM}$ solution in $\left.50: 50 \mathrm{CH}_{3} \mathrm{CN}: \mathrm{H}_{2} \mathrm{O}\right)$, followed by the addition of 100 equivalents of $\mathrm{NaCNBH}_{3}(10.4 \mu \mathrm{L}$ of a $200 \mathrm{mM}$ solution in $\mathrm{CH}_{3} \mathrm{CN}$ ). The reactions were allowed to proceed at room temperature for $16 \mathrm{hrs}$. After the reactions were complete the wells were pooled, precipitated with cold ethanol 
and purified by reverse-phase HPLC to give $2 \mu \mathrm{mol}$ of final product as determined by $\mathrm{OD}_{260}(\varepsilon=978,699)$. Since 192 synthons and 192 encoding tags were used each synthon was encoded by 1 tag.

\section{Characterization of library}

\section{Cycle 1 Analysis}

Plate 1 well A1 ligation (1 component)

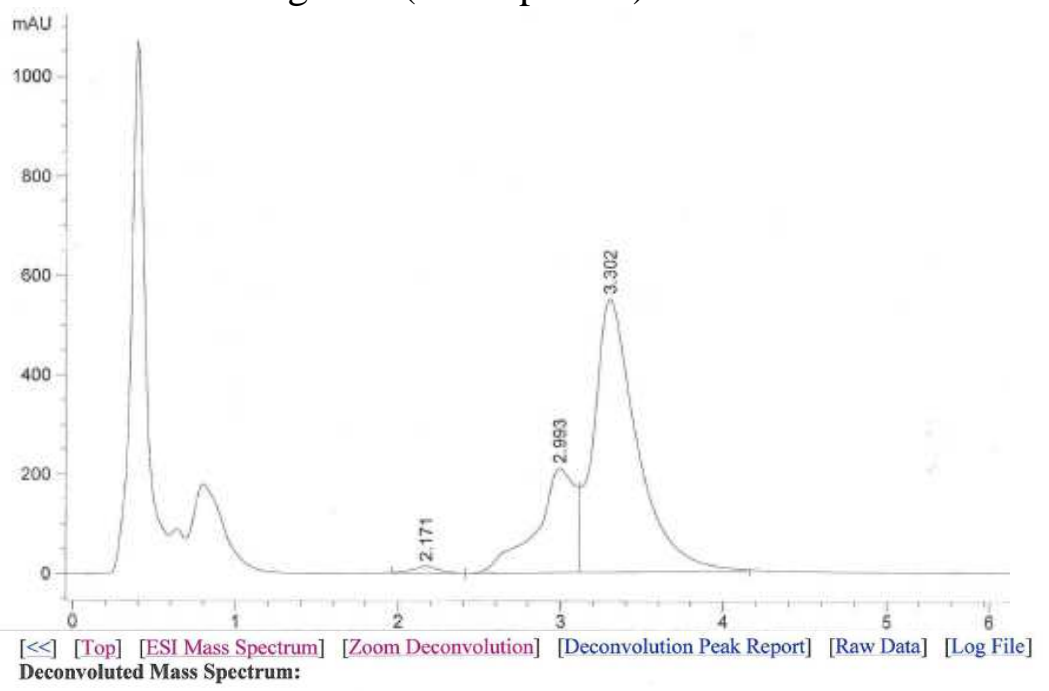

$[<<$ [Top] [EST Mecss Spectrum] [Zoom Deconvolution] [Deconvolution Peak Report] [Raw Data] [Log File]

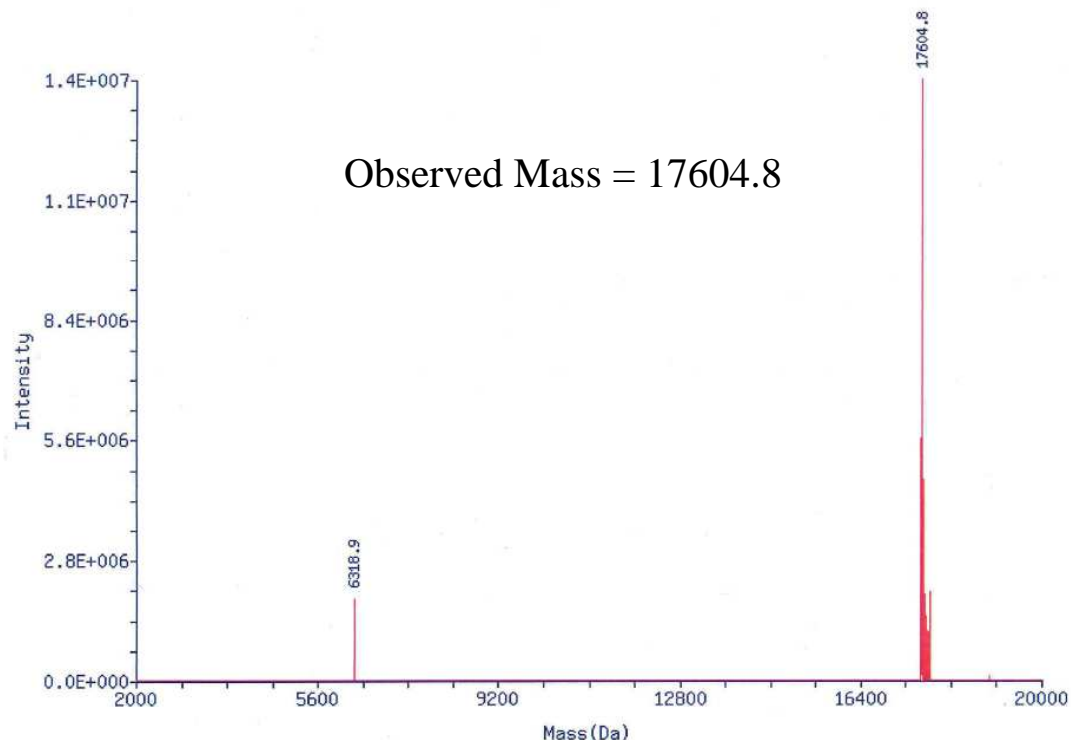

Figure 3. LC chromatogram and deconvoluted mass spectrum of ligation of plate 1 well A1.

Plate 1 well A1 acylation 


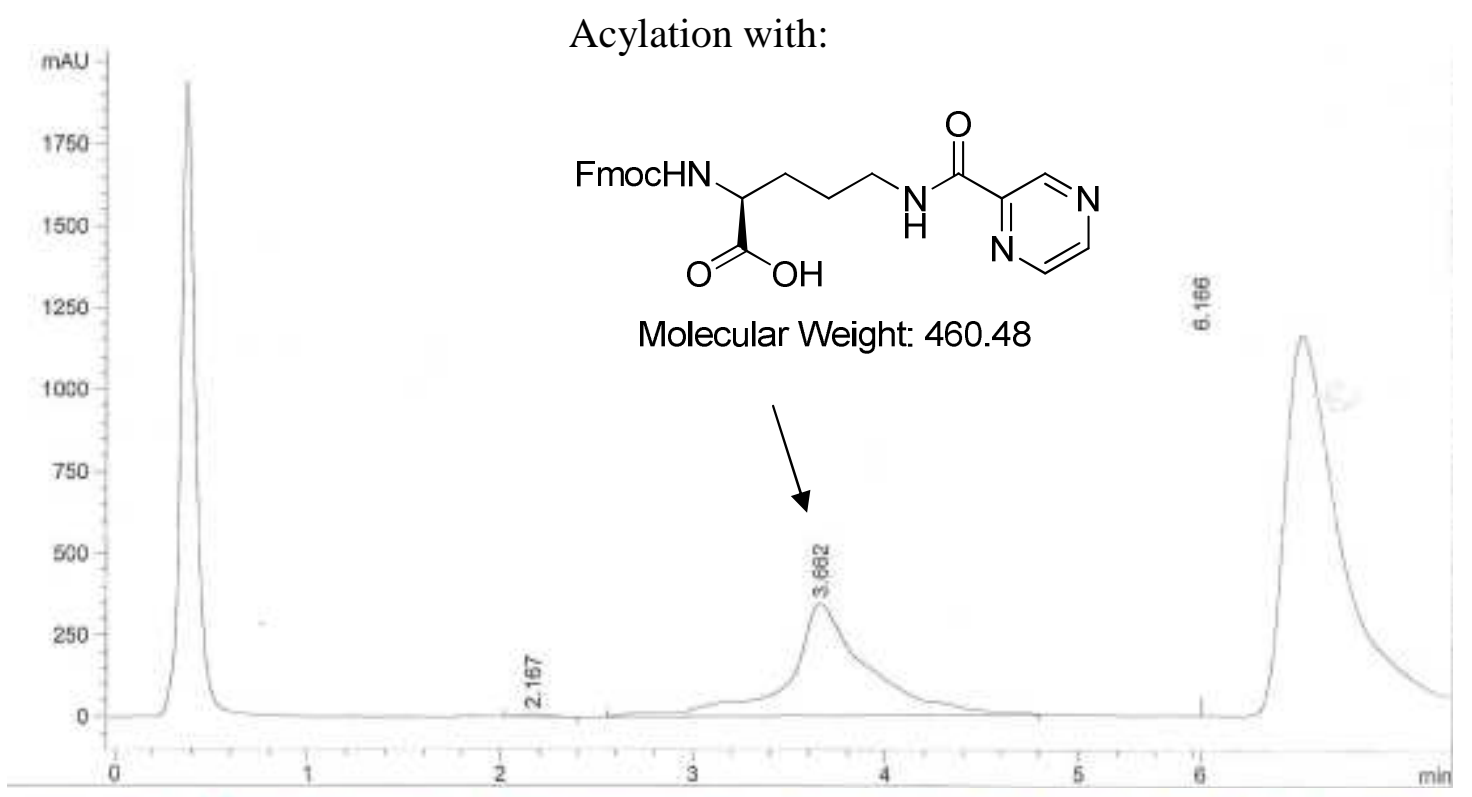

[<] [Top] [ESI Mass Spectrum] [Zoom Deconvolution] [Deconvolution Peak Report] [Raw Data] [Log File] Deconvoluted Mass Spectrum:

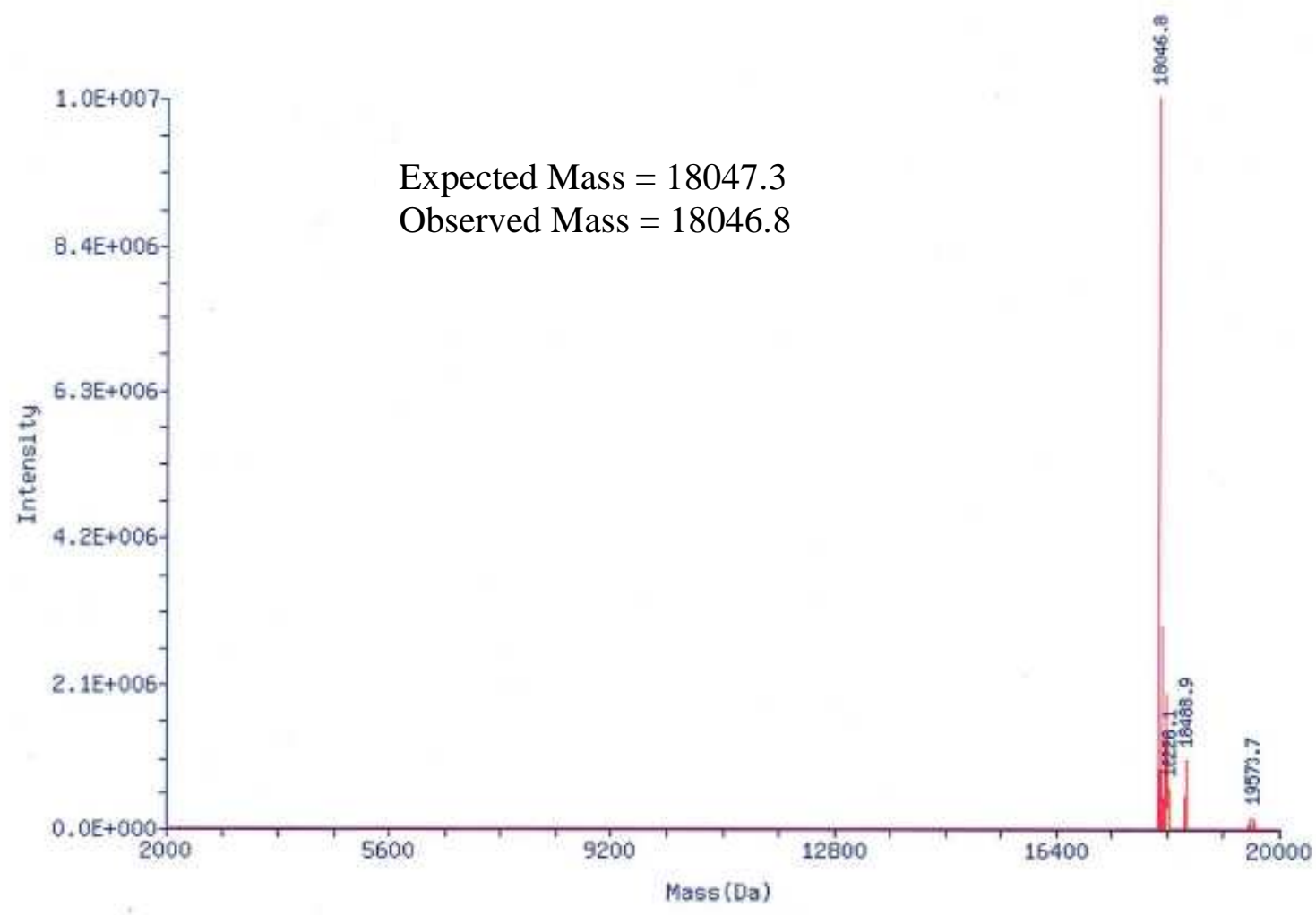

Figure 4. LCMS analysis of acylation step for well A1 from plate 1.

Crude pooled cycle 1 product (192 components) 


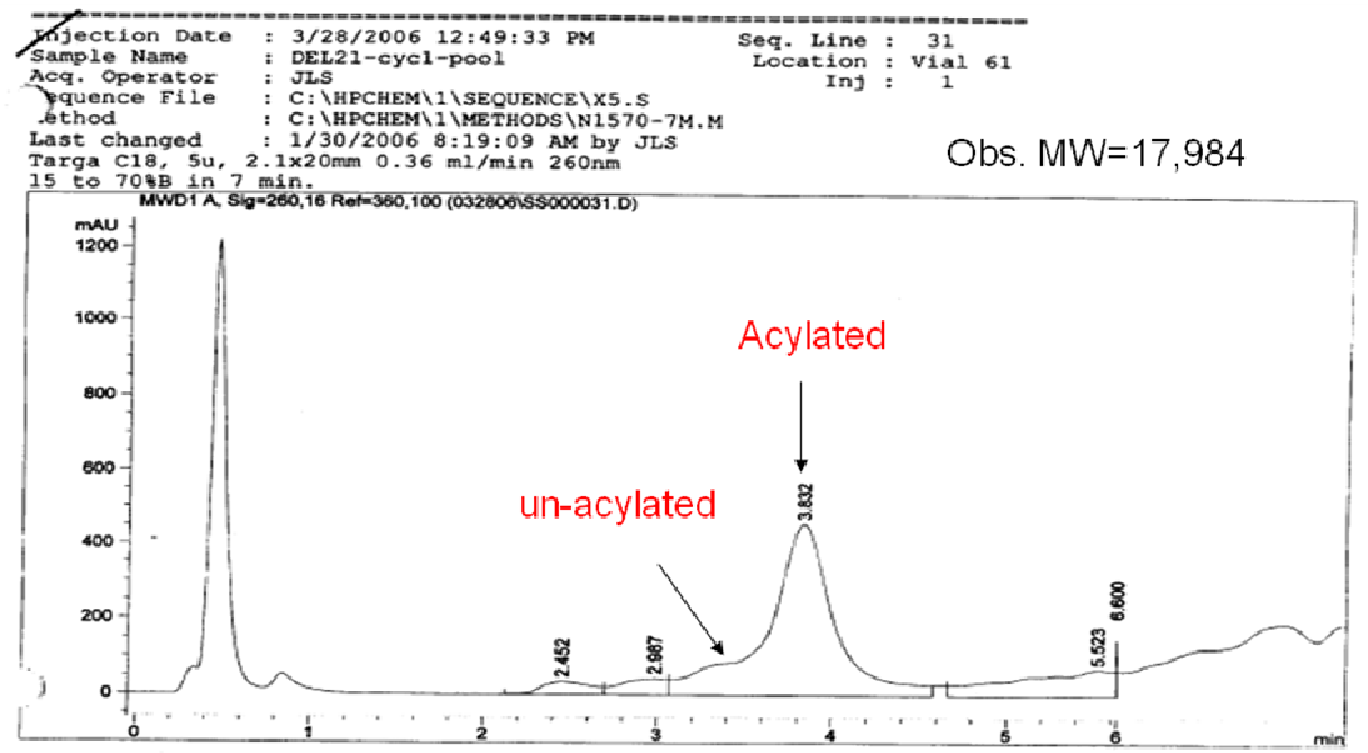

[《] [Top] [ESI Mass Spectrum] [Zoom Deconvolution] [Deconvolution Peak Report] [Raw Data] [Log File] Deconvoluted Mass Spectrum:

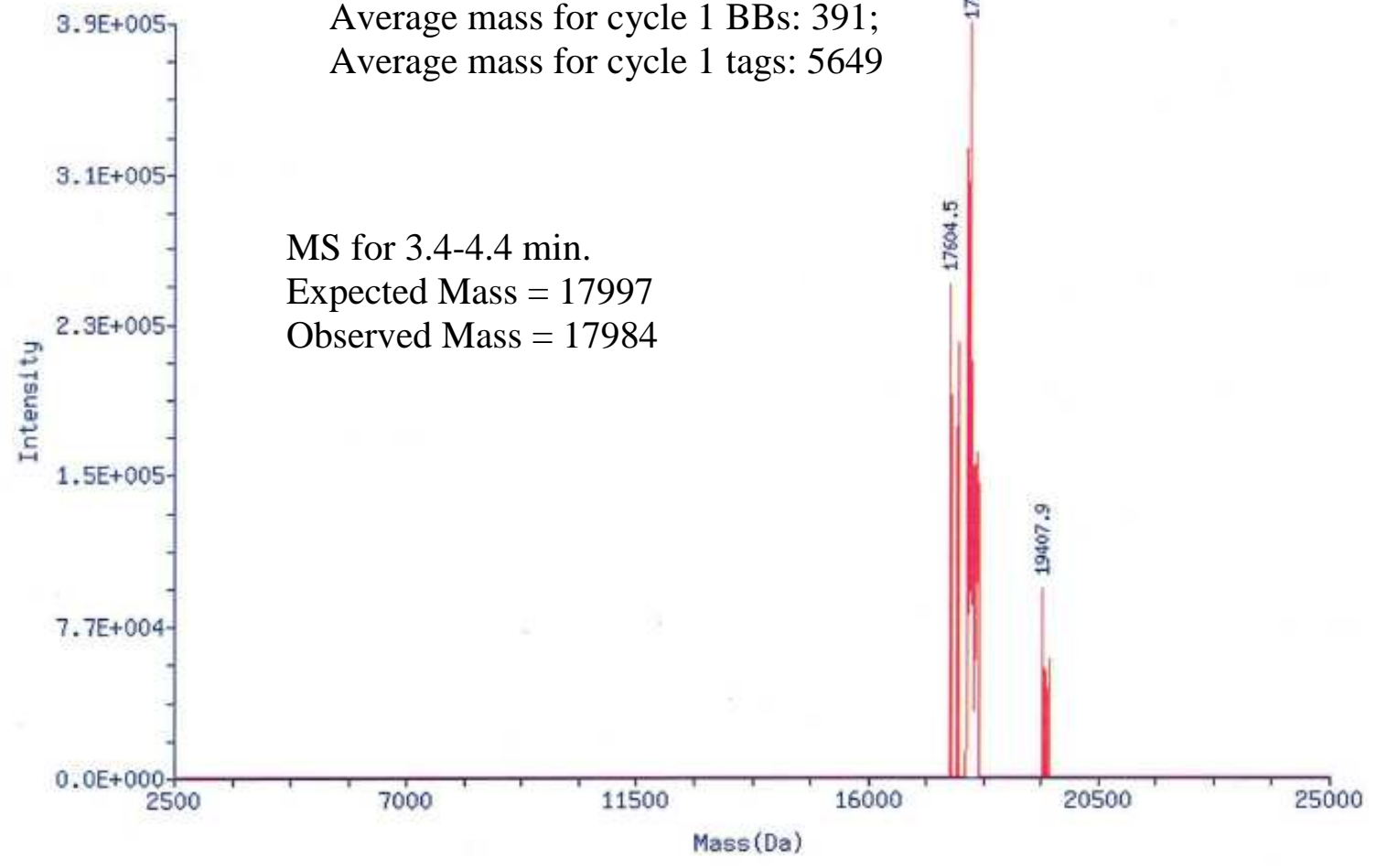

Figure 5. LC chromatogram and deconvoluted mass spectrum of crude Cycle 1 pooled product.

Deprotection: 


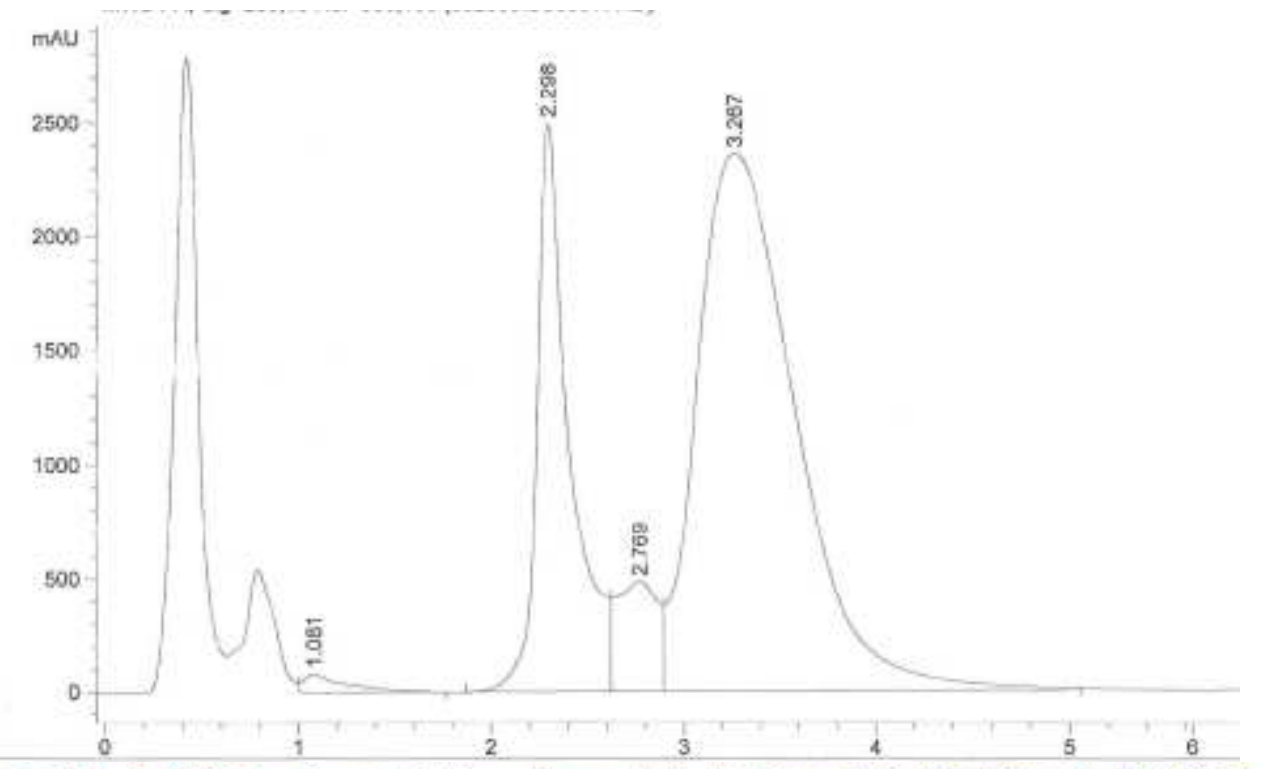

[<] [Top] [ESI Mass Spectrum] [Zoom Deconvolution] [Deconvolution Peak Report] [Raw Data] [Log File] Deconvoluted Mass Spectrum:

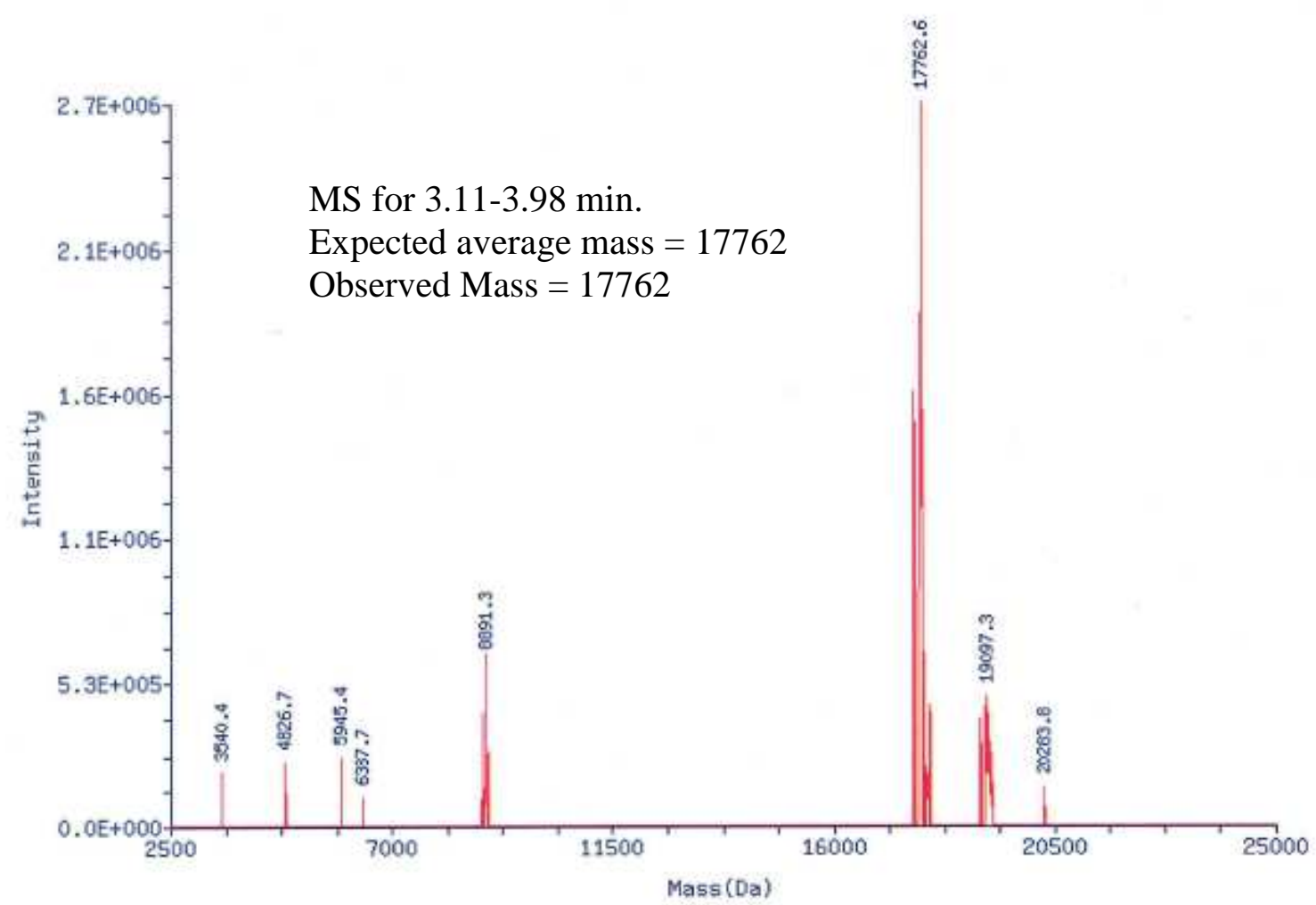

Figure 6. LC chromatogram and deconvoluted mass spectrum of crude Cycle 1 pooled product after Fmoc deprotection. 
After scaffold installation, followed by purification

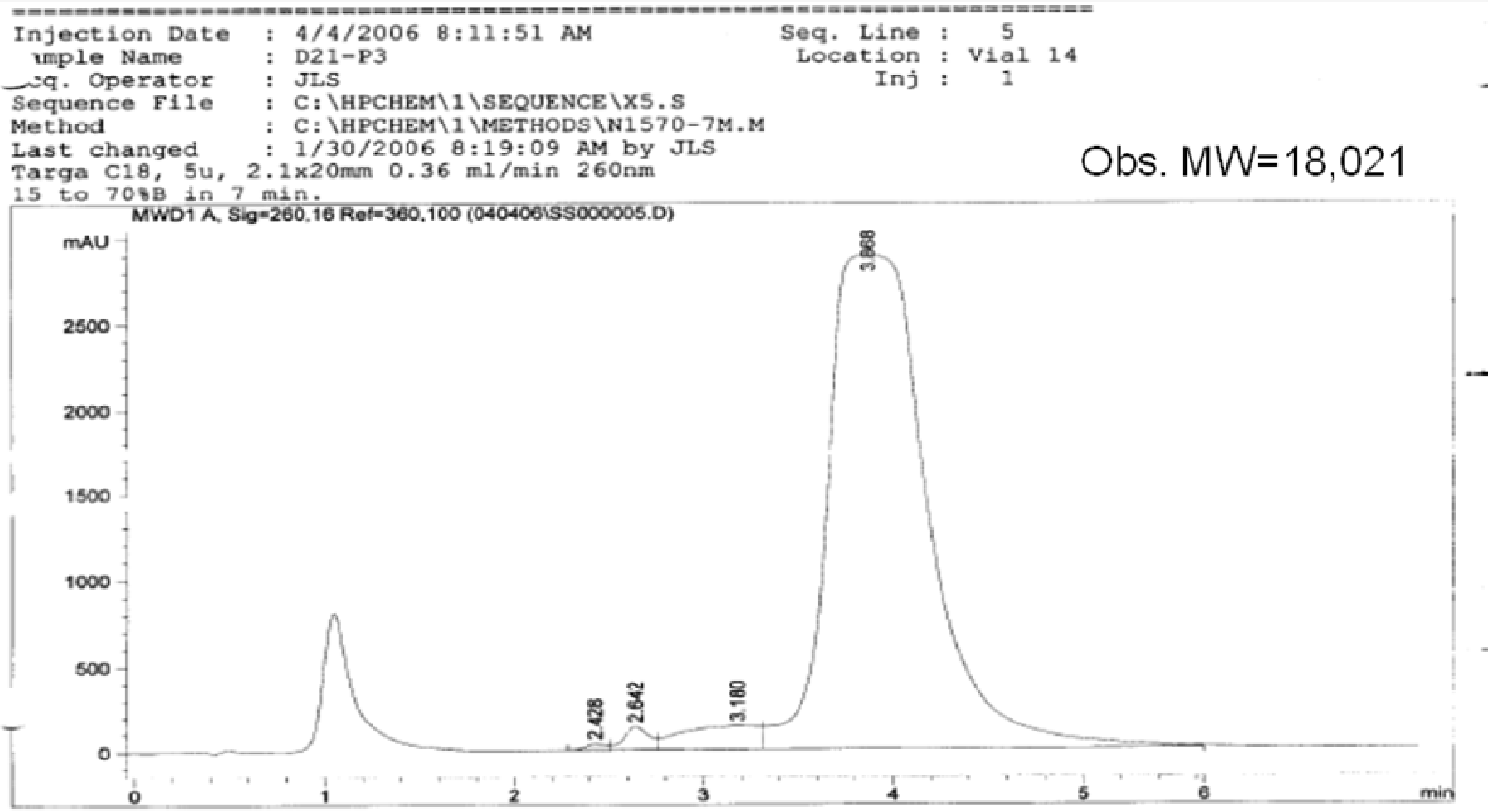

[<<] [Top] [ESI Mass Spectrum] [Zoom Deconvolution] [Deconvolution Peak Report] [Raw Data] [Log File] Deconvoluted Mass Spectrum:

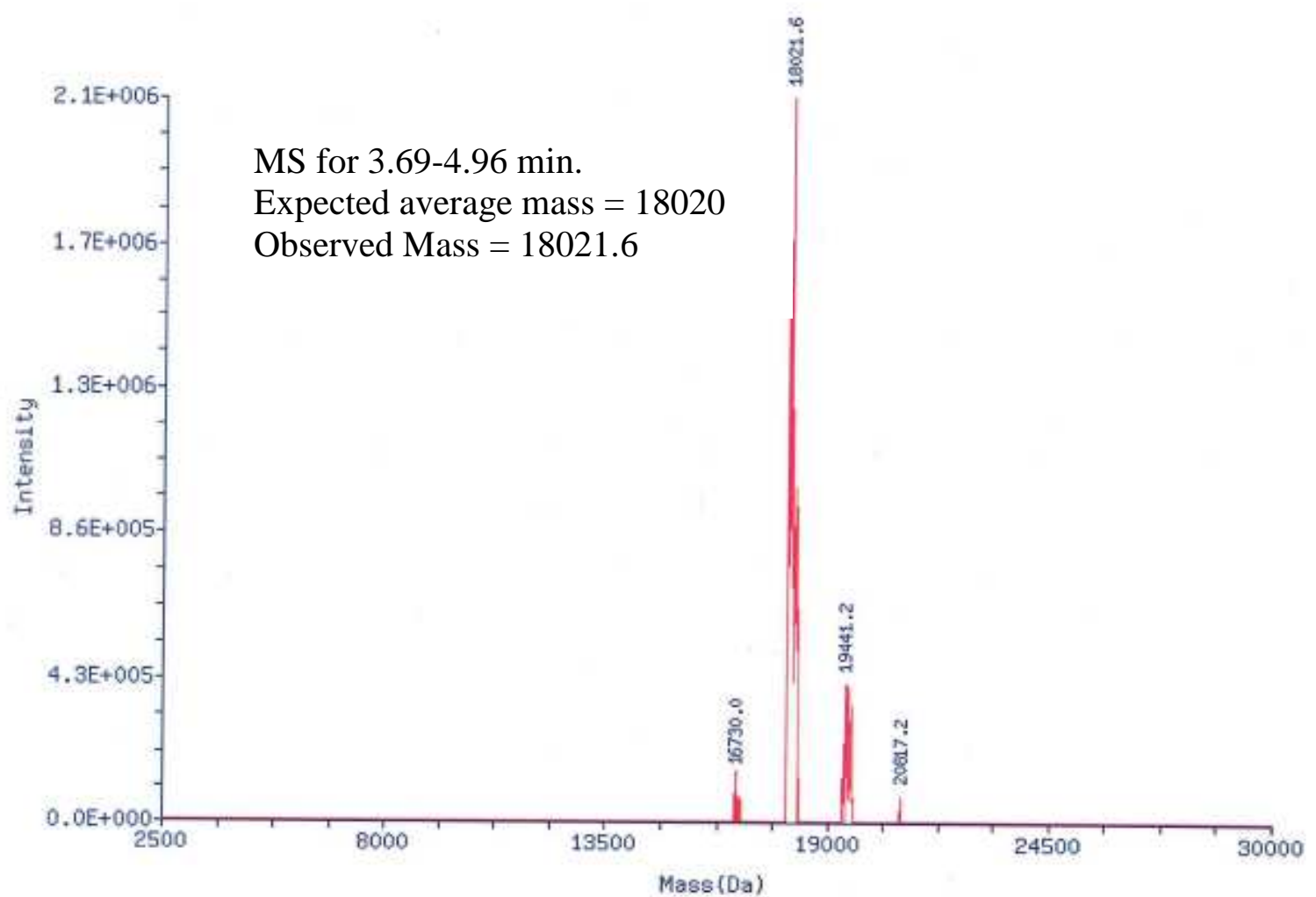

Figure 7. LC chromatogram and deconvoluted mass spectrum of scaffold installed product after reverse phase LC purification. 


\section{Cycle 2 Analysis}

Plate 1 well B2 ligation (192 components):

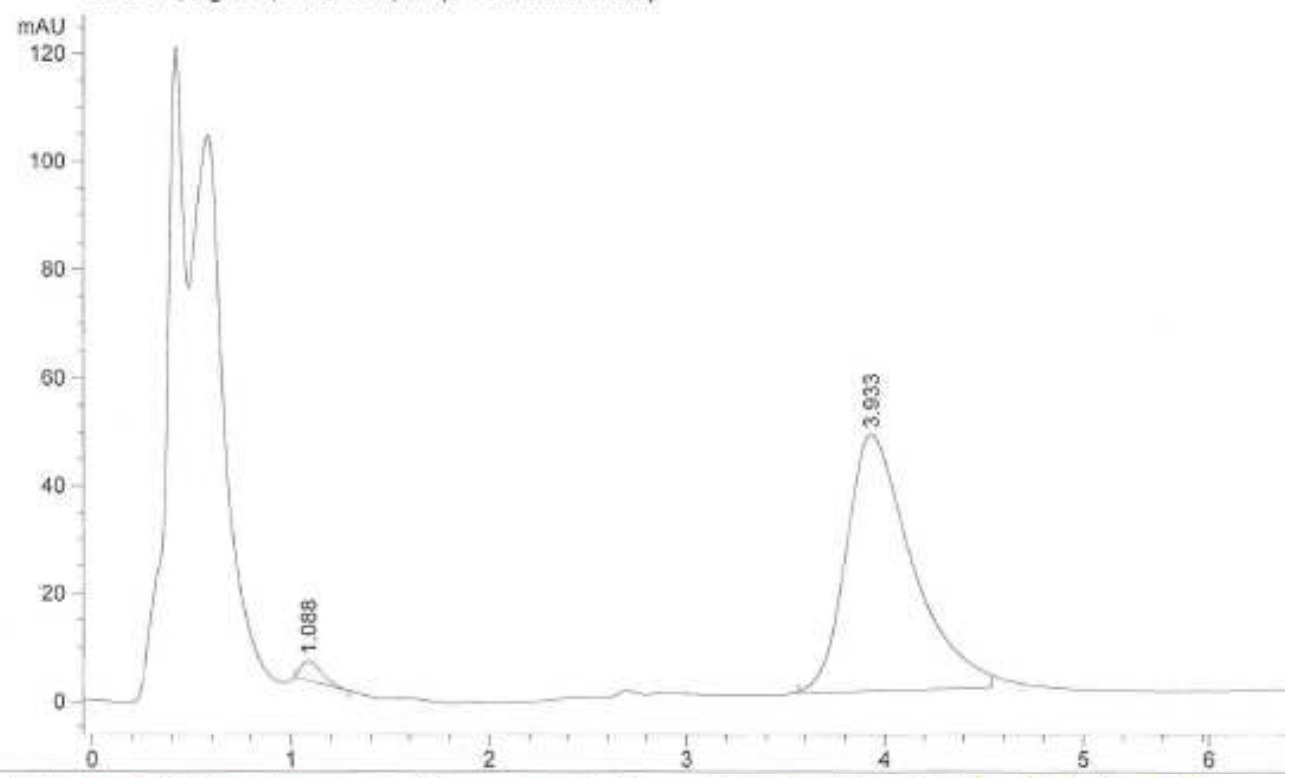

[<<] [Top] [ESI Mass Spectrum] [Deconvolution] [Deconvolution Peak Report] [Raw Data] [Log File] Zoom Display Deconvoluted Mass Spectrum:

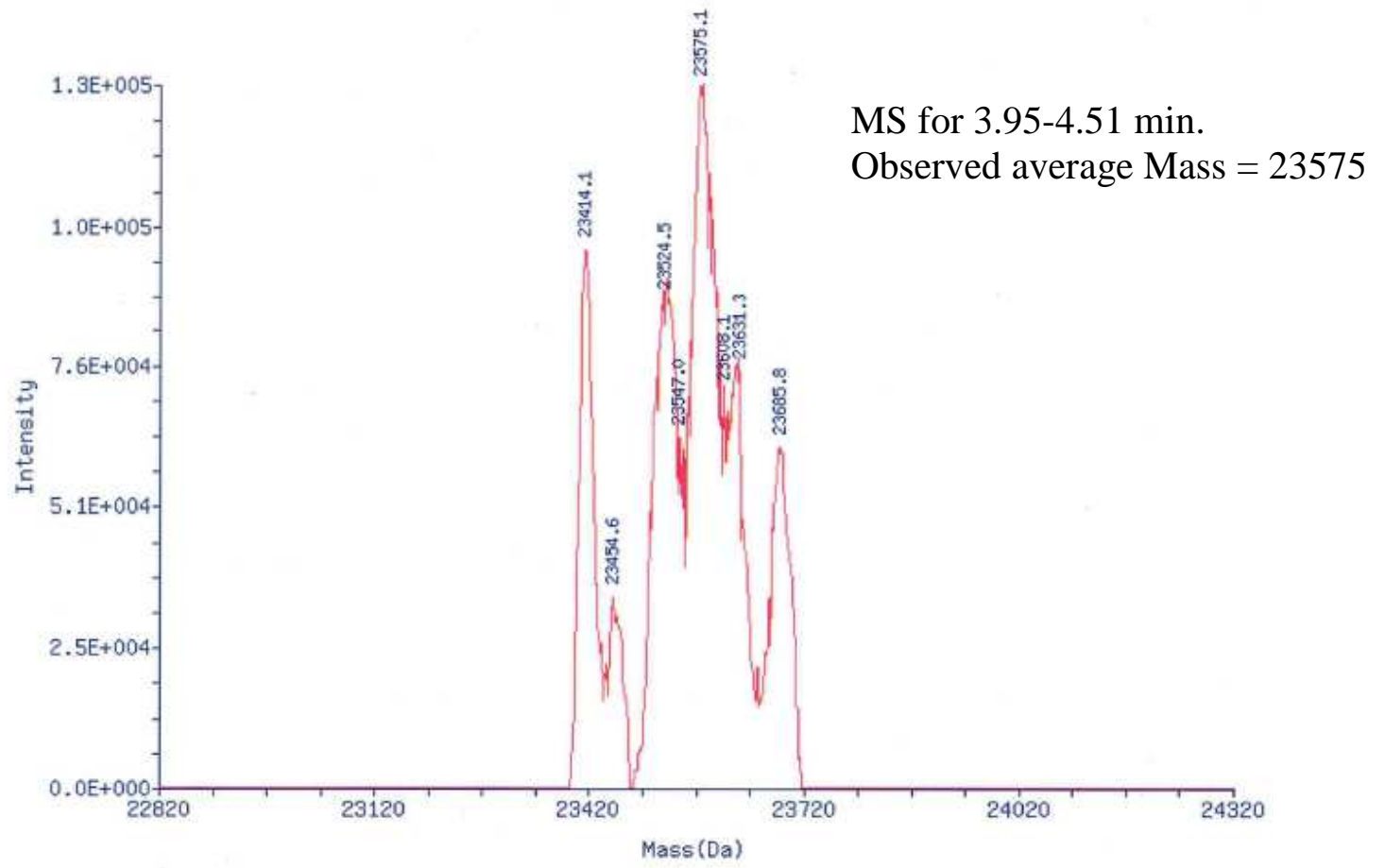

Figure 8. LC chromatogram and deconvoluted mass spectrum of Cycle 2 ligation for well B2 of plate 1.

Plate 1 Well B2 coupling (192 components): 


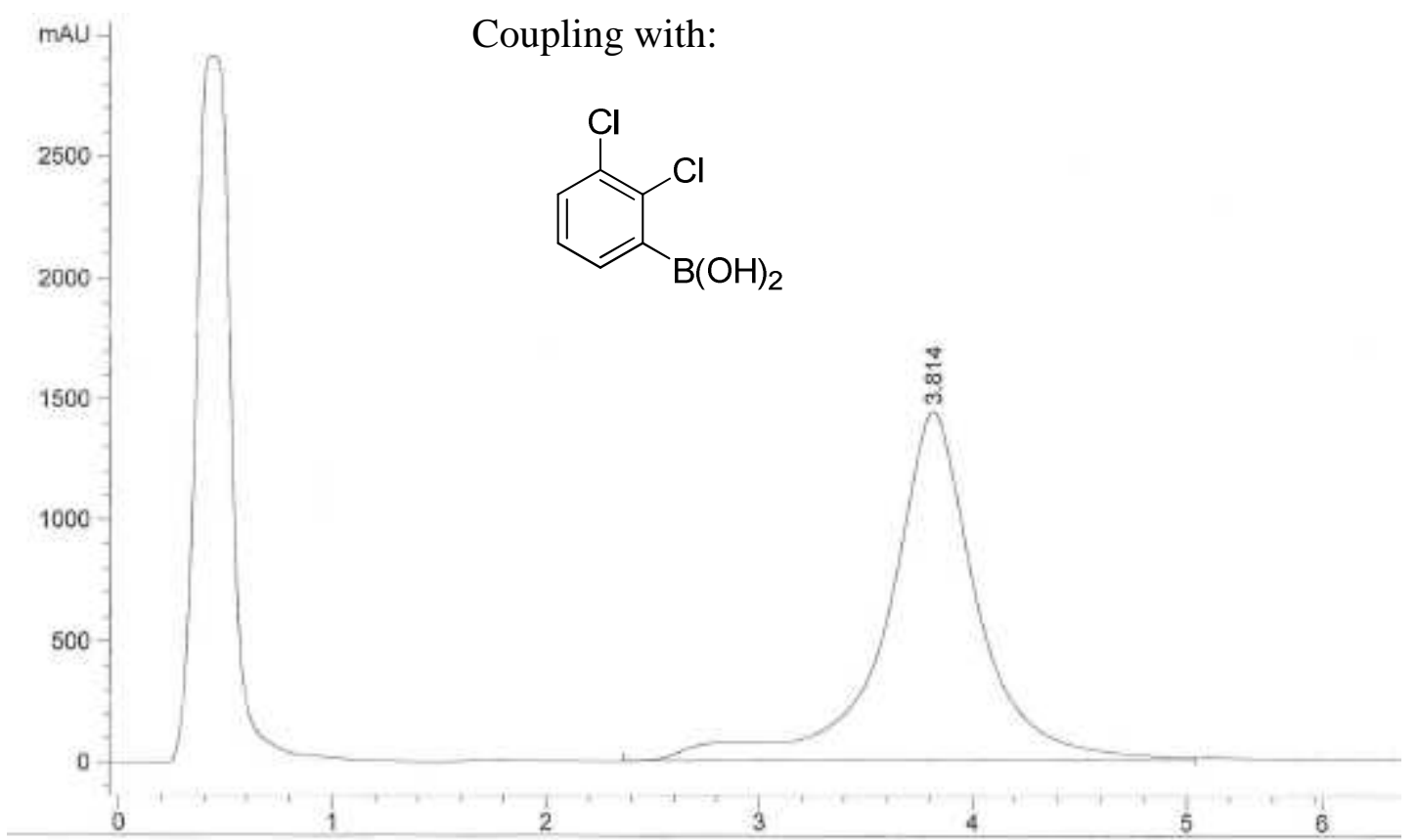

[ $\ll$ ] [Top] [ESI Mass Spectrum] [Deconvolution] [Deconvolution Peak Report] [Raw Data] [Log File] Zoom Display Deconvoluted Mass Spectrum:

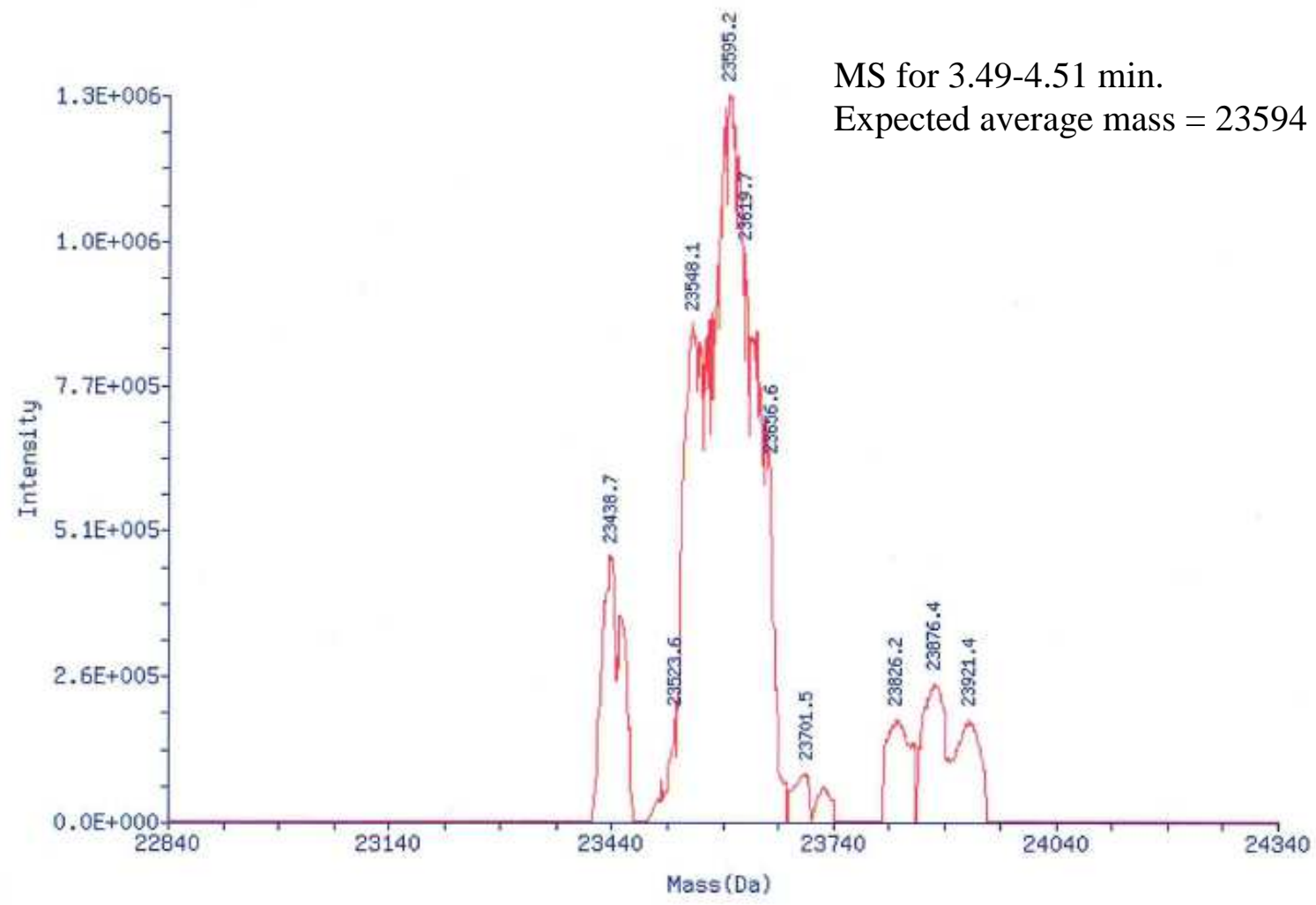

Figure 9. LC chromatogram and deconvoluted mass spectrum of Cycle 2 chemistry for well B2 of plate 1 . 
Another coupling example (Plate 1 well D8):
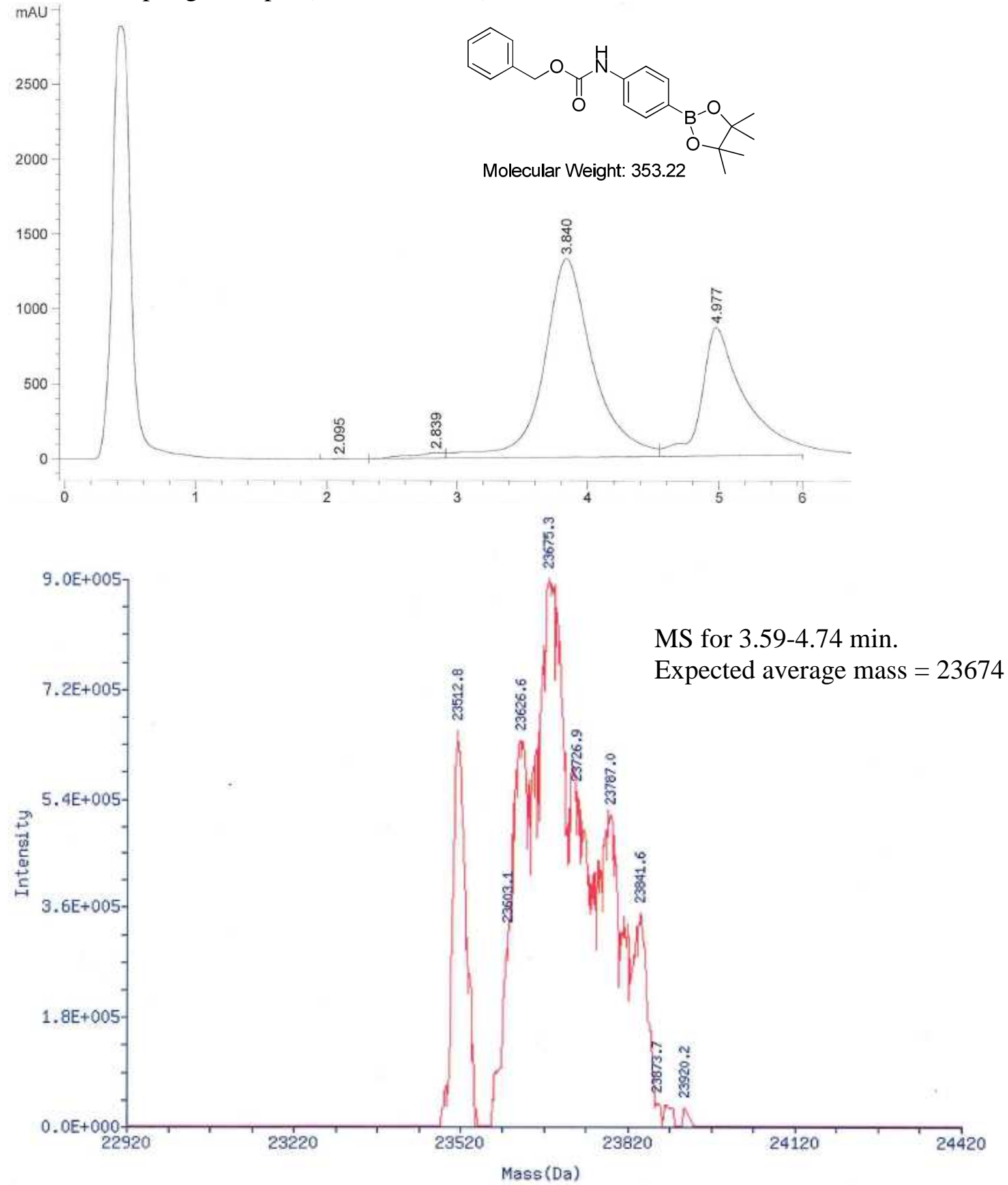

Figure 10. LC chromatogram and deconvoluted mass spectrum of Cycle 2 chemistry for well D8 from plate 1 .

Cycle 2 pooled product: 


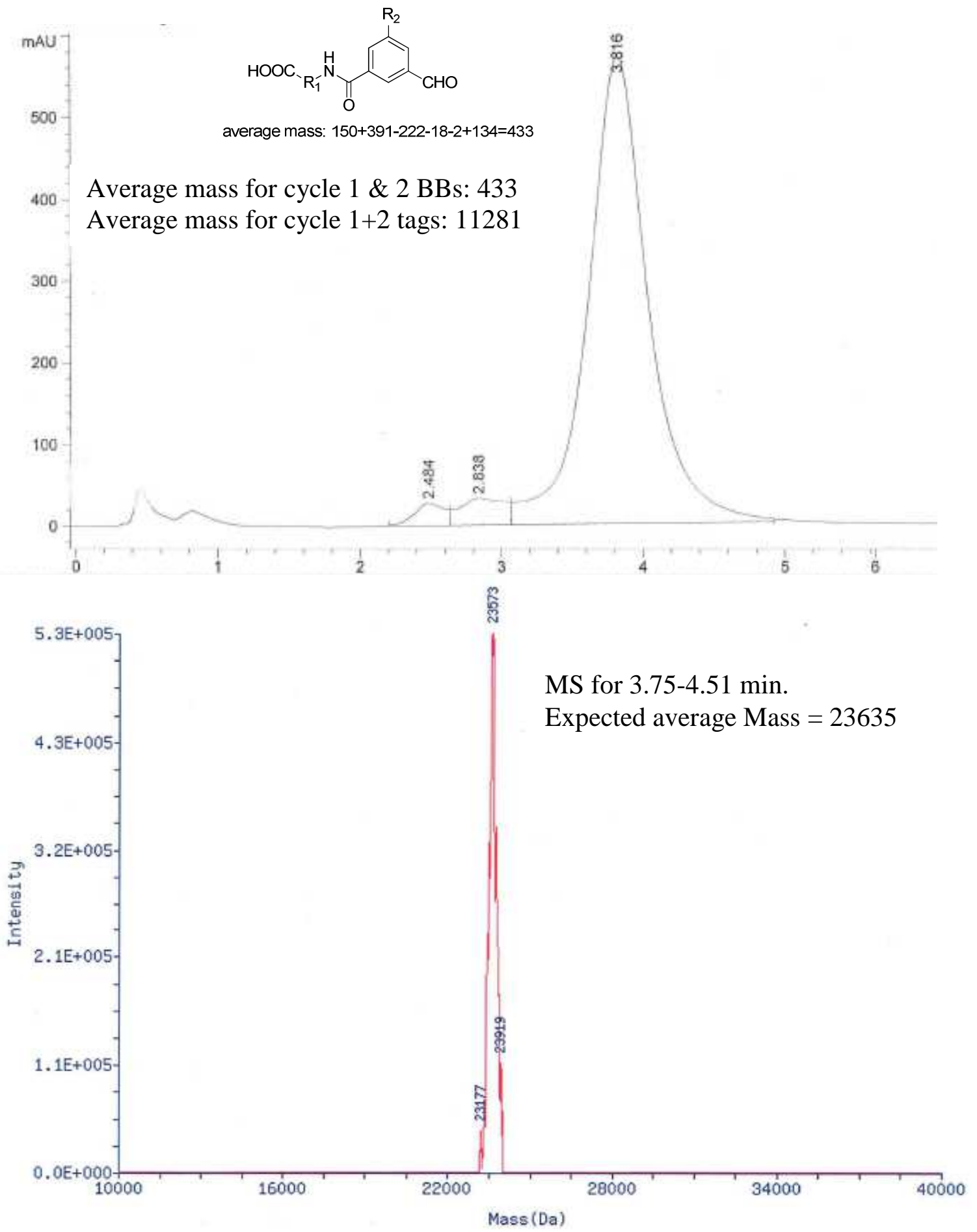

Figure 11. LC chromatogram and deconvoluted mass spectrum of pooled Cycle 2 product after purification.

Cycle 3 Analysis

Plate 1 Well A1 Ligation (18240 components) 


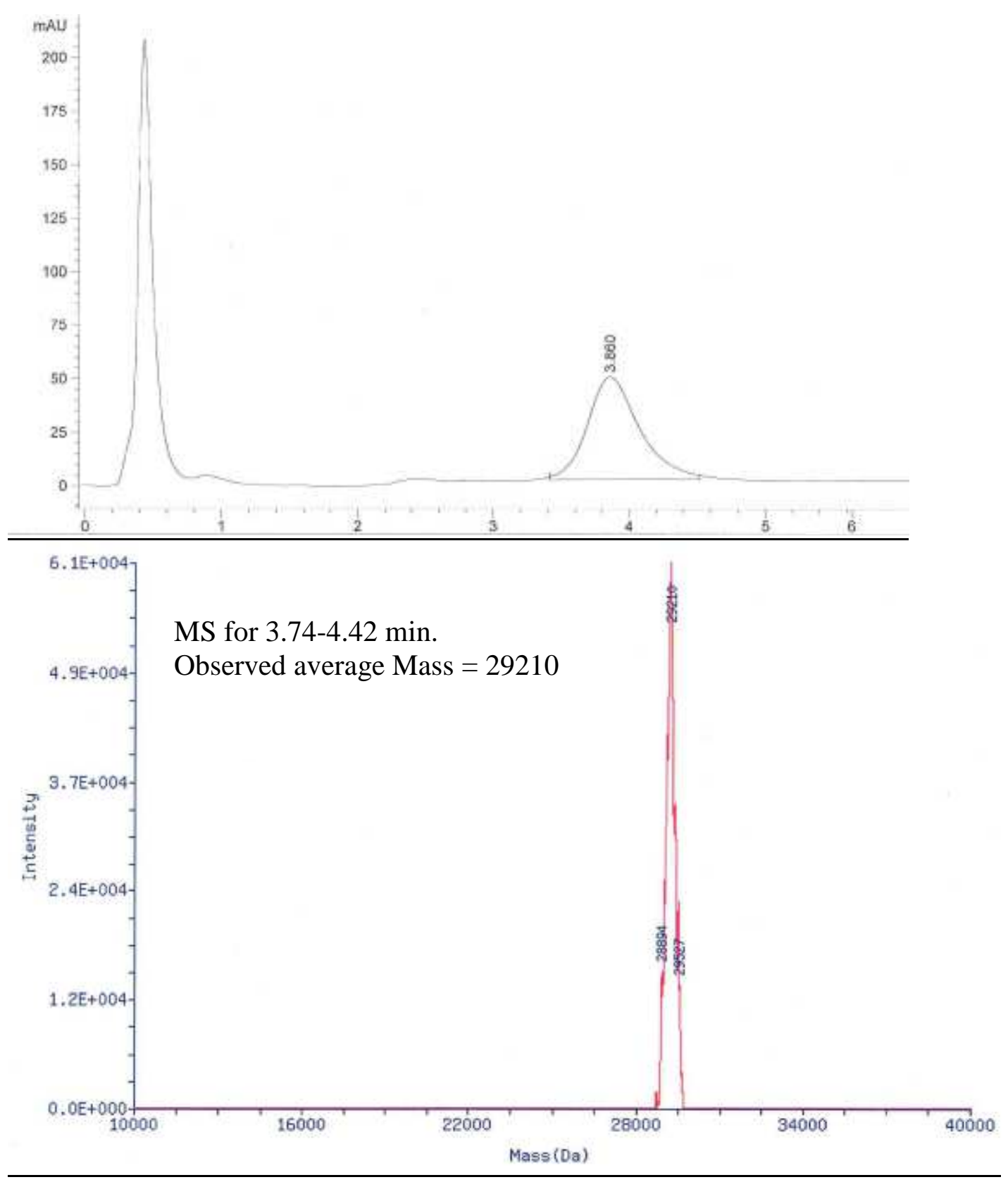

Figure 12. LC chromatogram and deconvoluted mass spectrum of Cycle 3 ligation from well A1 of plate 1 .

Plate 1 Well A1 reductive amination (18240 components) 

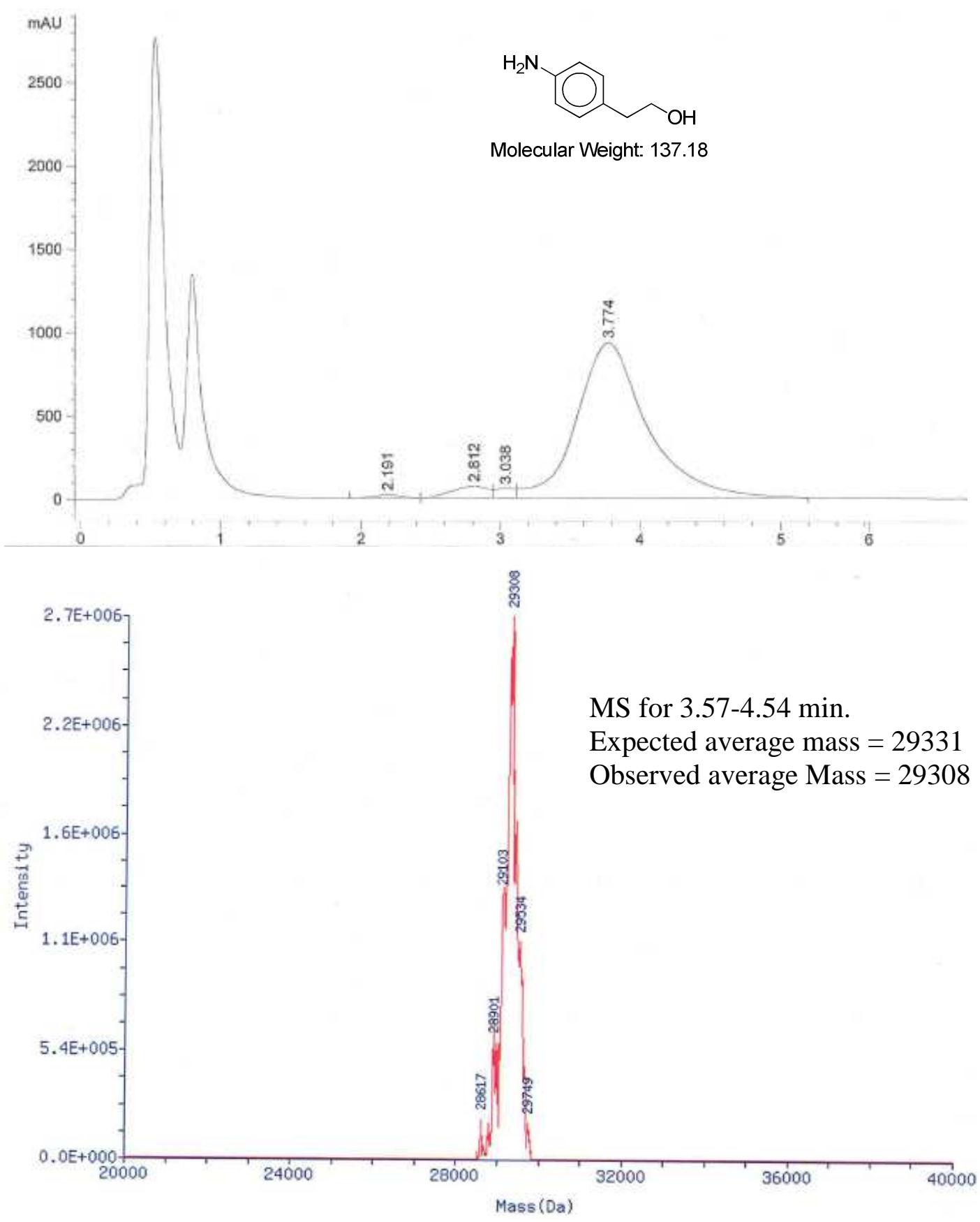

Figure 13. LC chromatogram and deconvoluted mass spectrum of Cycle 3 reductive amination from well A1 of plate 1 .

$\underline{\text { Final library, pooled and purified }}$ 

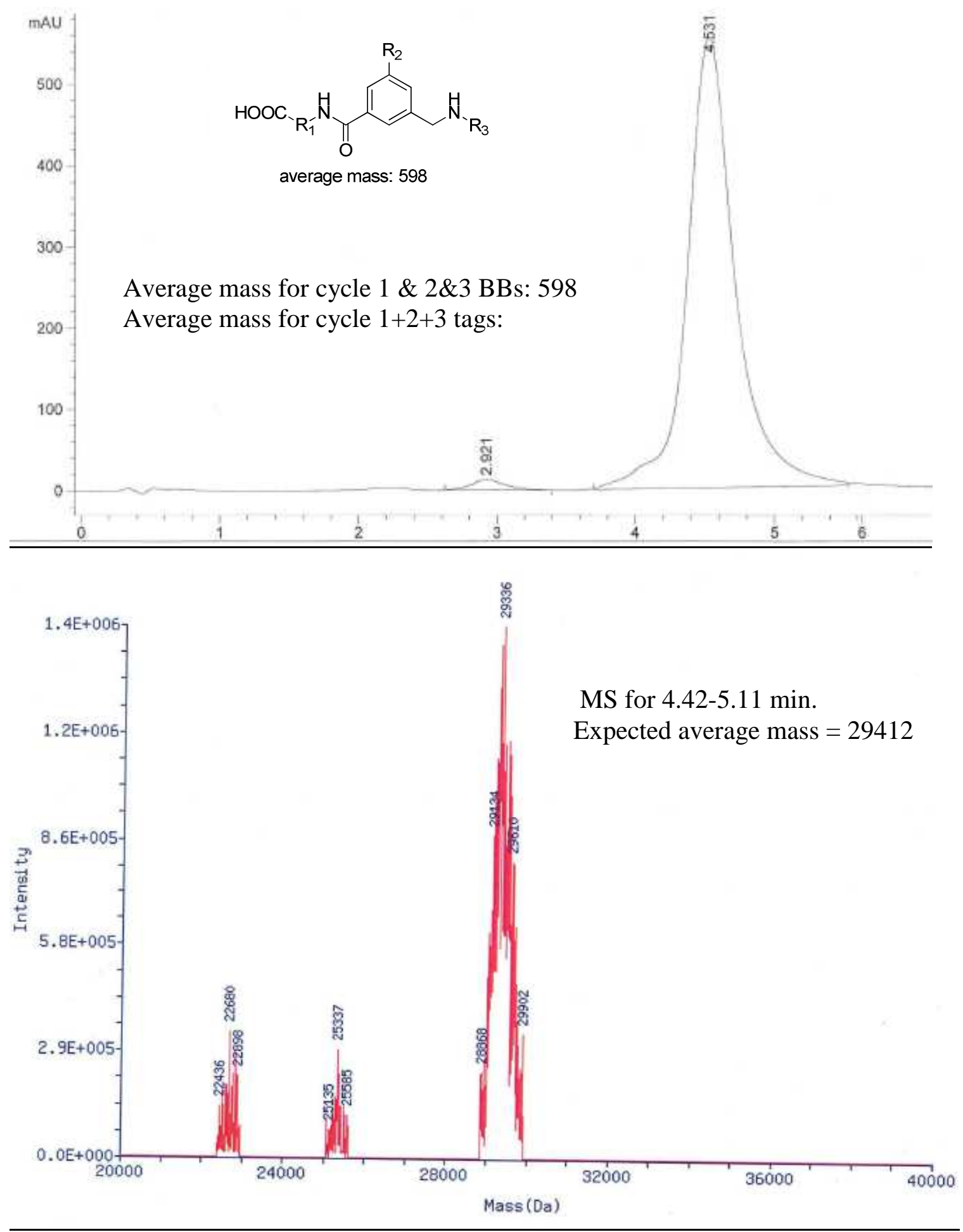

Figure 14. LC chromatogram, raw ESI mass spectrum, and deconvoluted mass spectrum of DEL-A final product (ca. 3.5 million components) 